\title{
REGIONAL-SCALE COMPOSITIONAL AND SIZE FIDELITY OF ROCKY INTERTIDAL COMMUNITIES FROM THE PATAGONIAN ATLANTIC COAST
}

\author{
FERNANDO M. ARCHUBY, ${ }^{1}$ MARIANA ADAMI,${ }^{2}$ JULIETA C. MARTINELLI,${ }^{3}$ SANDRA GORDILLO,${ }^{4}$ GABRIELA M. BORETTO, ${ }^{4}$ AND \\ MARIANO E. MALVÉ 5 \\ ${ }^{1}$ Instituto de Investigación en Paleobiología y Geología, UNRN, Av. Roca No. 1242 (8332) General Roca (Río Negro), Argentina \\ ${ }^{2}$ División Zoología Invertebrados, Museo de la Plata, FCNYM-UNLP, La Plata, Argentina \\ ${ }^{3}$ Department of Biological Sciences, Macquarie University, NSW 2109, Australia \\ ${ }^{4}$ CICTERRA, CONICET-UNC, Córdoba, Argentina \\ ${ }^{5}$ Facultad de Ciencias Exactas, Físicas y Naturales. Universidad Nacional de Córdoba, Córdoba, Argentina \\ e-mail: farchuby@unrn.edu.ar
}

\begin{abstract}
The use of rocky intertidal assemblages in paleoecology and conservation paleobiology studies is limited because these environments have low preservation potential. Here, we evaluate the fidelity between living intertidal mussel bed communities (life assemblages or LAs) and mollusk shell accumulations (death assemblages or DAs) from the environmentally harsh Patagonian Atlantic Coast. LAs were sampled from rocky mid-intertidal and mussel-dominated habitats while DAs were collected from the high water mark at beaches in close proximity to the living intertidal community to assess live-dead mismatch at regional scales. DAs were restricted to the subset of species in the DAs that inhabit rocky intertidal habitats. A total of 37,193 mollusk specimens from 15 intertidal species were included in the analysis. Ten species were present in LAs, 14 in DAs, and nine were shared by LAs and DAs. DAs showed higher diversity, less dominance, and more rare species than LAs. Despite finding good agreement in species composition between DAs and LAs within the same region, smaller species are underrepresented, as shown by differences in size-frequency distributions. Our findings indicate that the composition of DAs is a result of the combined effects of spatial and temporal averaging, size-related biases, and biases related to low detectability of boring and vagile species in LAs. Thus, DAs do not accurately detect within-provincial latitudinal gradients in composition. However, DAs clearly capture differences between the Argentine-Magellanic Transition Zone and the Magellanic Province, indicating that DAs are informative tools at regional scales despite the environmental harshness to which they are subjected.
\end{abstract}

\section{INTRODUCTION}

The degree of fidelity between living communities and their fossil counterparts constrains the usefulness of preserved assemblages to reconstruct past ecosystems. Determining how much of the biological signal reaches shell beds after the influence of biological and physical agents and time averaging, and how this preservability varies in time and space, remains one of the key steps in paleontological analysis (Fürsich 1978, 1995; Kidwell 1985, 1986, 2001; Kidwell et al. 1986; Fürsich and Aberhan 1990; Kidwell and Flessa 1995; Kowalewski et al. 2003; Tomašových et al. 2006). Previous contributions have found that there is fairly good agreement between the species composition of living assemblages (LAs) and the co-occurring death assemblages (DAs) in marine environments (e.g., Fürsich and Flessa 1987; Kidwell 2001, 2002, 2013; see examples in Kidwell and Bosence 1991) as well as in other settings and/or taxa, such as land snails (Yanes et al. 2008; Yanes 2011), fresh water mollusks (De Francesco et al. 2013; Erthal et al. 2011; Tietze and De Francesco 2012), marine mammals (Liebig et al. 2003), ungulate mammals (Miller 2011, 2012), nonvolant terrestrial mammals (Miller et al. 2014), and small mammals (Terry 2010; see other examples in Kidwell and Tomašových 2013). However, the degree of similarity between living communities and the corresponding dead remains shows a large variation (Kidwell 2001), particularly among marine benthic communities (Kidwell and Bosence 1991; Zuschin et al. 2000; Zuschin and Oliver 2003; Albano and Sabelli 2011; Feser and Miller 2014). The dissimilarities between LAs and DAs in marine soft-bottom environments can be largely explained by the effect of time averaging and probably less by taphonomic biases (Tomašových and Kidwell 2009, 2010, 2011; Kidwell and Tomašových 2013). This finding has also been established in several other contributions both from terrestrial and marine ecosystems (Kidwell and Tomašových 2013 and references therein). A conservative estimation of the effects of time averaging on DAs indicates that in a few decades to centuries, alpha diversity increases and beta diversity decreases at small spatial scales, species dominance is reduced, and rare species become more common (i.e., rank abundance distributions become flatter) (Tomašových and Kidwell 2010).

The composition of snapshot-like LAs (i.e., sampled at a single time) is not necessarily an accurate estimate of the composition of the source assemblages from which DAs originate (i.e., integrated over a longer time). Short-term changes in species composition in living communities can be substantial (Kidwell and Bosence 1991) and compositional variations can also be enhanced by anthropogenic effects (Kidwell 2007). In addition, sampling living marine communities can be costly and logistically complicated (Warwick and Light 2002). An example of the changes that living communities experience over short time intervals that can strongly influence the results of discrete sampling (censuses) of LAs can be seen in the surf clam Mesodesma mactroides. This bivalve changed from being the dominant species in sandy beaches in Argentina to completely disappearing in less than a month due to a natural mass 
mortality event in 1995 (Fiori and Cazzaniga 1999; Dadon 2005). The populations recovered quickly because only the benthic life stages were affected. If samples from the living communities had been taken before and after the mass mortality event, they would have been drastically different. The mass mortality of Mytilus edulis caused by high temperature on rocky shores represents another example (Tsuchiya 1983) (see other examples documented in Fiori and Cazzaniga 1999 and Dadon 2005). In this regard, one of the benefits of DAs is that they average out these atypical short-term events, providing a more conservative overview of community composition at broader temporal and spatial scales (Fürsich 1978; Fürsich and Aberhan 1990; Kidwell and Bosence 1991; Tomašových and Kidwell 2010; Kidwell and Tomašových 2013). The inertia of DAs to short-term changes in species composition thus turns them into good proxies for long-term or regional-scale studies of benthic assemblages.

In the southwestern Atlantic, among the most conspicuous benthic assemblages are the rocky intertidal communities. These habitats invariably consist of dense and extended monocultures of small Brachidontes mussels, which are very important ecosystem engineers (Olivier et al. 1966a, 1966b; Bertness et al. 2006; Adami et al. 2008, 2013). Other larger mytilids (e.g., Mytilus spp., Aulacomya atra) are also present along the rocky shores, but at low population densities (López Gappa et al. 1990; Adami et al. 2004). Intertidal mussels frequently occur as multilayered beds (Guiñez and Castilla 1999) of considerable structural complexity (Commito and Rusignuolo 2000). These mussel beds buffer other species against biotic and abiotic fluctuations, and produce an array of microhabitats that facilitates persistence of associated organisms (Silliman et al. 2011). Studies conducted in Patagonia have shown that extreme desiccation is an important and unique feature of these intertidal mussel-dominated beds (Bertness et al. 2006). Strong dry winds, combined with low rainfall probably make these shores one of the most physically demanding rocky intertidal systems in the world. These mussel beds offer an exceptional opportunity to assess the preservability of rocky intertidal communities by quantifying fidelity between LAs and DAs. In addition, most live-dead studies in marine environments have focused on soft- or mixed-sediment habitats (but see Zuschin et al. 2000; Zuschin and Oliver 2003; Zuschin and Stachowitsch 2007), while compositional fidelity in rocky-bottom intertidal environments remains poorly known.

Here, we evaluate the correspondence between mollusk DAs from Patagonian beaches that represent natural sediment traps for inhabitants of rocky intertidal communities (Martinelli et al. 2013, and additional data gathered for this study), and a database of intertidal mussel bed communities from the same area (Adami et al. 2013). We seek to establish the degree of fidelity with which compositional and ecological information from living communities is represented by DAs in this climatically harsh environment. To do this, we (1) compare LAs and DAs within two biogeographic provinces and (2) assess the regional variability of fidelity in species composition across the boundary between two biogeographic provinces (i.e., Argentine and Magellanic). Rocky shores are dominated by erosion and do not tend to accumulate any sediment, consequently dead shells are destroyed or quickly transported away to other habitats. Therefore, the nature of live-dead comparison is based on LAs and DAs sampled at different sites within the same regions, allowing regional-scale inferences on the preservability of ecological signals within and between biogeographic provinces. We hypothesize that DAs maintain the species composition from the communities from which they derive, even after suffering the biases brought about by various taphonomic agents, and the effects of time averaging. In particular, we predict that the DAs will share roughly the same species composition and abundance with the LAs. In agreement with previous studies, we also anticipate that DAs will be enriched in larger specimens (Fürsich and Oschmann 1993; Valentine et al. 2006), and will show higher taxonomic

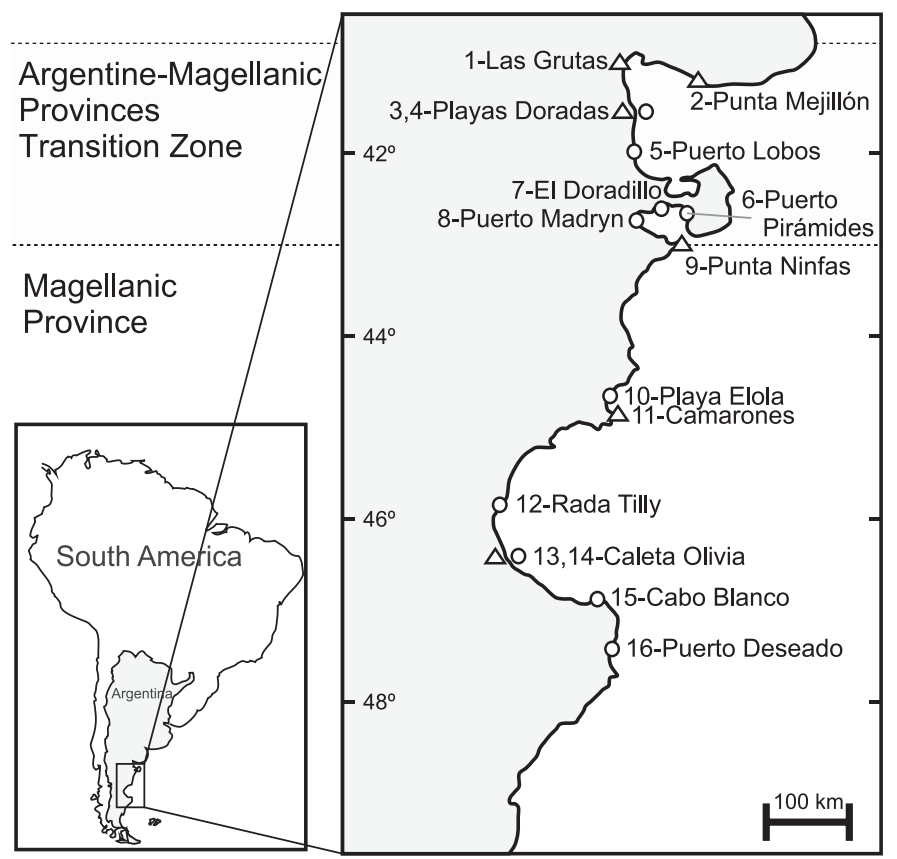

FIG. 1.-Map of the study area with the sampled localities. Triangles represent living assemblages (LA) and circles represent death assemblages (DA). For more details see Table 1 .

richness and evenness than LAs (Fürsich and Aberhan 1990; Olszewski and Kidwell 2007; Kidwell and Tomašových 2013).

\section{MATERIALS AND METHODS}

\section{The Study System}

The study region encompasses $1,500 \mathrm{~km}$ along the south Argentine Atlantic coastline $\left(41-48^{\circ} \mathrm{S}\right.$; Fig. 1), including the Transition Zone between the Argentine and Magellanic Biogeographic Provinces $\left(41^{\circ} \mathrm{S}\right.$ and $43^{\circ} \mathrm{S}$; Balech and Ehrlich 2008) and the northern part of the Magellanic Province $\left(43-48^{\circ} \mathrm{S}\right)$. Both LAs and DAs from this area are exposed to high-energy flows during high tides (mean tidal amplitude ranges from 1.76 to $6.74 \mathrm{~m}$, while maximum tidal amplitude varies between 2.46 and $9.57 \mathrm{~m}$ (Balech and Ehrlich 2008; Servicio de Hidrografía Naval 2012). Temperatures are usually low (min SST ranges between 4.2 and $10.8^{\circ} \mathrm{C}$, max SST ranges between 12.9 and $20.1^{\circ} \mathrm{C}$; Table 1) and winds are frequent and strong $(45-140 \mathrm{~km} / \mathrm{h}$; Camacho 1979; Bertness et al. 2006).

The configuration of the Argentinean Patagonian coastal margin is the result of several factors mainly related to sea-level variations associated with glacioeustatic climate changes as well as geotectonic and isostatic compensation processes (Clapperton 1993; Rostami et al. 2000; Schellmann and Radtke 2000, 2010; Pedoja et al. 2011). The geographic distribution and the characteristics of rocky shores of our study area are listed in Table 1.

Mussel Beds in Rocky Intertidal Shores.-Several mytilid species are found in intertidal mussel beds along southwestern Atlantic coasts (Scarabino et al. 2006; Ríos 2009; Adami et al. 2013; Trovant et al. 2013). The study area is dominated by two small-sized Brachidontes species that form dense beds along with other species in minor proportions (i.e., Mytilus spp.) (Olivier et al. 1966a, 1966b; López Gappa et al. 1990; Adami et al. 2004, 2008; Bertness et al. 2006). Brachidontes rodriguezii dominates the rocky intertidal from Buenos Aires to northern Patagonia 
TABLE 1.-Details of the localities included in this study.

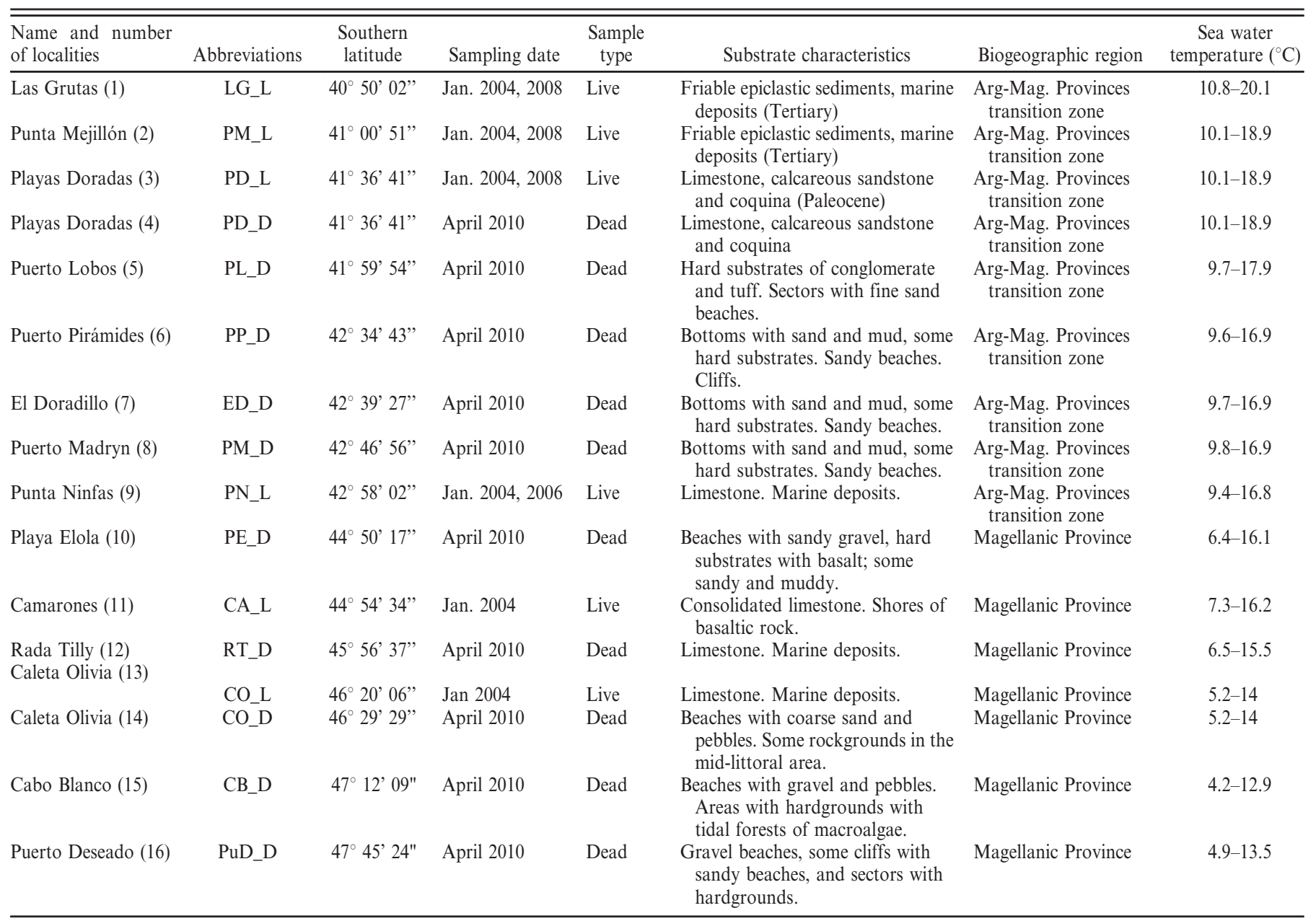

(Penchaszadeh 1973; López Gappa et al. 1990; Adami et al. 2004; Adami et al. 2013), and Brachidontes (= Perumytilus) purpuratus is most abundant from northern Patagonia to the Pacific Ocean coast up to Ecuador (Bernard 1983). Both species coexist in the Transition Zone between the Argentine and Magellanic Biogeographic provinces (41$43^{\circ} \mathrm{S}$ ) and, although both species are morphologically and biologically very similar, the structure of their mussel beds and their accompanying fauna differ significantly (Arribas et al. 2013).

\section{Methods}

Two databases were used for the live-dead comparisons. The first one has exhaustive counts of living mollusks (LAs) from the middle rocky intertidal from six localities along the Atlantic coast of Patagonia (Fig. 1, Table 1). The second database contains counts of intertidal mollusks from death assemblages sampled at ten localities within same region (Fig. 1, Table 1). Because rocky-bottom habitats are dominated by erosional processes, and hence do not accumulate shells, DAs were collected at beaches where shells from intertidal and subtidal habitats accumulated, and locations of LAs thus do not precisely coincide with locations of DAs. The selection of sites where DAs were sampled was designed to capture the spatial variation in species composition of shell accumulations in the study area. However, out of 16 localities, three localities with DAs are located close to localities with LAs (localities 3 and 4 at Playas Doradas, localities 10 and 11 at Playa Elola/Camarones, and localities 13 and 14 at Caleta Olivia), thus forming three pairs of LAs and DAs that can be compared at smaller spatial scales (see Table 1 for latitude details). To make the samples of DAs comparable with those from LAs, we selected the subset of species that occur in rocky intertidal habitats on the basis of evidence independent from LA composition (i.e., from published literature and/or field observation of some of the authors, namely FA, SG, MA and JM, during different field seasons) (Table 2).

Sampling.-Living assemblages (LAs) were sampled at six localities between 2004 and 2008 (Table 1) (Adami et al. 2013). In every locality five or six replicates of $14 \times 14 \mathrm{~cm}\left(200 \mathrm{~cm}^{2}\right)$ were taken and all living specimens counted. The replicates were randomly spread at each sampling site. Samples were always obtained from the mid-intertidal zone, aiming at the centroid of patches with $100 \%$ mussel cover developed over gently sloping surfaces (Fig. 2A, B). Samples were sieved using a $0.5 \mathrm{~mm}$ mesh, and mussels and other macrofaunal organisms were retrieved.

Death assemblages (DAs) were collected in April 2010 at ten localities along the Atlantic coast of Patagonia (Table 1). The high-water mark was sampled every $10 \mathrm{~m}$ using a $0.5 \mathrm{~m} \times 0.5 \mathrm{~m}$ quadrat (Fig. 2C, D). Shells were carefully hand collected (not sieved) from the sediment surface and in some cases as deep as $10 \mathrm{~cm}$ if the beach was pebbly. Depending on density, shells from 10 to 20 quadrats were combined to obtain at least 200 complete shells. Bivalve individuals were estimated as articulated shells plus the most abundant of left or right valves. 
TABLE 2.-Summary of species found in the death assemblages. Zonation (subtidal, intertidal), substrate type (H: hard, S: soft), life habit (Ep: epifaunal, In: infaunal) and species documented for intertidal rocky-bottom substrates (DRI*).

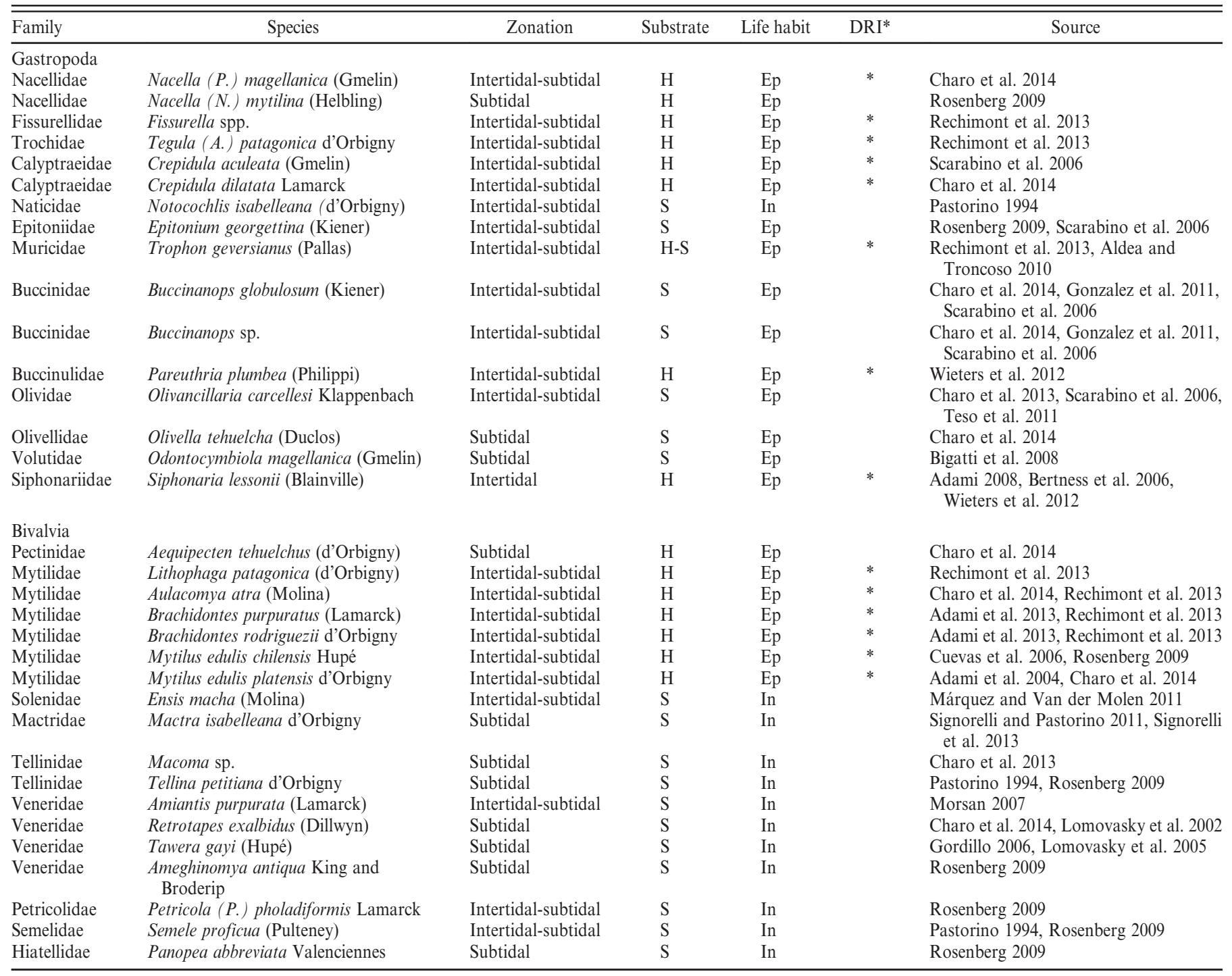

Univariate and Multivariate Analyses. - Species richness (S) and the PIE index (probability of interspecific encounter) were calculated for all LAs and DAs using PAST (Hammer et al. 2001). PIE is an evenness index related to Simpson's index of diversity (Hulbert 1971; Hammer and Harper 2006). Owing to the different sample sizes we also estimated species richness with rarefaction for $n=301$ with PAST (Hammer et al. 2001). Differences in abundance of the most common species between LAs and DAs were graphically compared with bar plots. These plots were constructed for Playas Doradas (localities 3 and 4), Playa Elola/ Camarones (localities 10 and 11), and Caleta Olivia (localities 13 and 14). Similar graphical representations were used to compare LAs and DAs at the provincial level. For analyses at the provincial scale we calculated the average percentage of each species across all localities in the corresponding biogeographic unit and type of sample (DA or LA).

A nonmetric multidimensional scaling (NMDS) was used to assess the similarity in species composition among LAs and DAs. A matrix was built with all the mollusk species from both databases (15 species; $n=37,193$ individuals). Absolute abundances were standardized to percentages, and then transformed with (a) square root and (b) presenceabsence. The Bray-Curtis distance was used for abundance data (Clarke 1993; Clarke and Warwick 2001; Clarke et al. 2006) and Sorensen coefficient for binary data (Hammer et al. 2001) (The Sorensen coefficient is equivalent to the Bray-Curtis distance applied to presence/absence data). Plots were rotated in order to arrange samples latitudinally. NMDS was performed with R (R Core Team 2014). Differences in species composition on the basis of percentages between LAs and DAs were assessed with a one-way PERMANOVA test (nonparametric multivariate analysis of variance) using Bray-Curtis as a distance index, using PAST (Hammer et al. 2001). This analysis was done for the whole matrix and by biogeographic province, with 9,999 permutations. The same procedure was used to compare species composition between biogeographic provinces for DAs and LAs.

In order to test the hypothesis that size-selective biostratinomic factors (tides, waves, and wind) affect the preservation of shells in DAs, we compared the size-frequency distributions of living and dead specimens of $B$. purpuratus and B. rodriguezii. We predicted that physical agents 

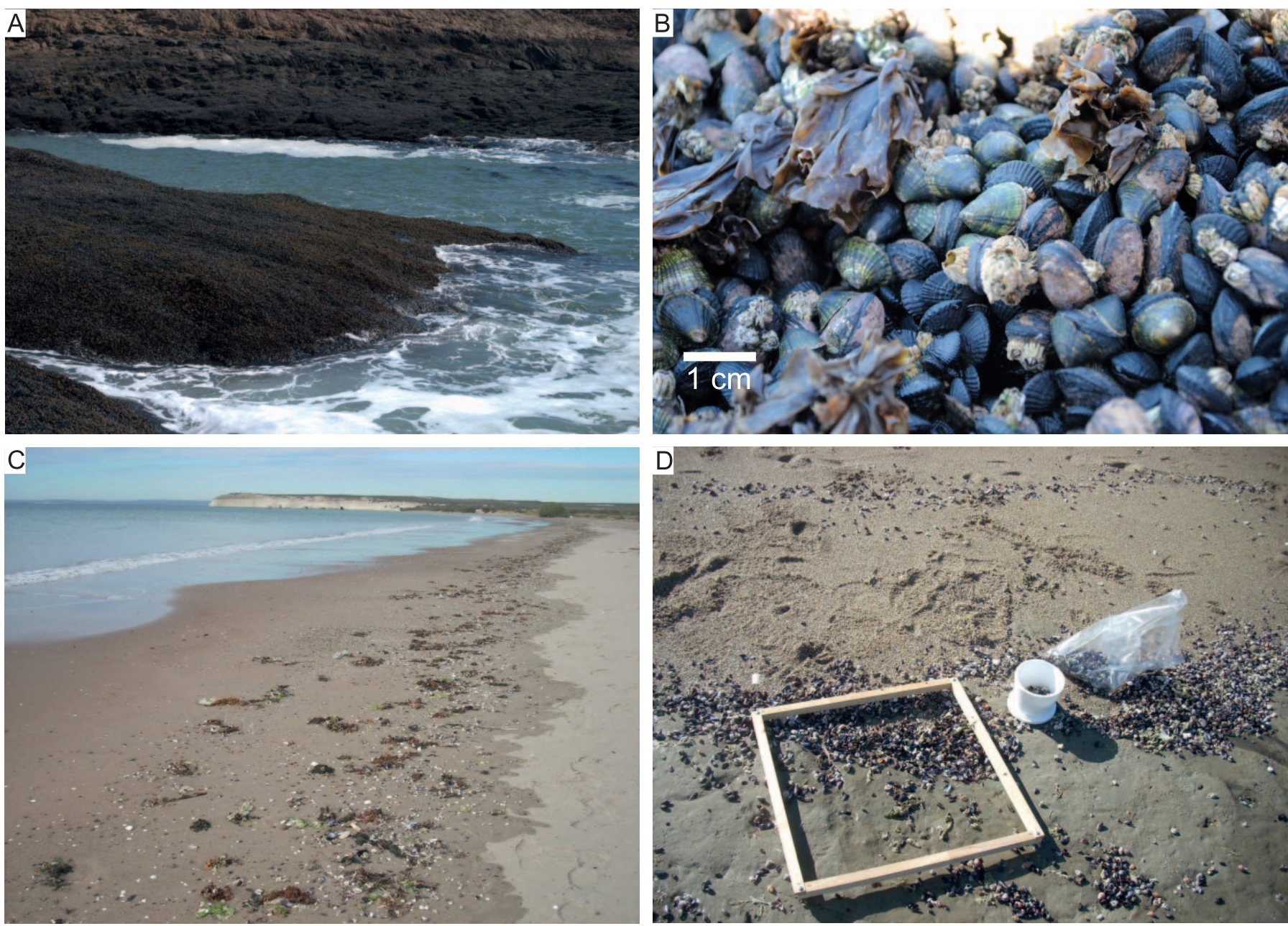

FIg. 2. - A) View of a mussel bed in Bahía Camarones (CA-L). B) Detail of a mussel bed. C) View of high tide line accumulation of dead shells. D) Sampling of death assemblages. The size of the quadrat is $50 \times 50 \mathrm{~cm}$.

TABLE 3.-Information of samples of living and death assemblages used in the analysis.

\begin{tabular}{|c|c|c|c|c|c|c|c|}
\hline $\begin{array}{l}\text { Sample } \\
\text { number }\end{array}$ & Locality & Abbreviation & Sample type & $\begin{array}{l}\mathrm{N} \text { (individuals } \\
\text { number) }\end{array}$ & $\begin{array}{c}\text { Species } \\
\text { richness (S) }\end{array}$ & $\begin{array}{l}\text { Rarefaction } S \\
(\mathrm{n}=301)\end{array}$ & PIE evenness \\
\hline 1 & Las Grutas & LG_L & Live & 3903 & 4 & 2.80 & 0.10 \\
\hline 2 & Punta Mejillón & PM_L & Live & 5573 & 6 & 5.00 & 0.30 \\
\hline 4 & Playas Doradas & PD_D & Dead & 634 & 11 & 10.65 & 0.57 \\
\hline 5 & Puerto Lobos & PL_D & Dead & 1778 & 11 & 10.11 & 0.72 \\
\hline 6 & Puerto Pirámides & PP_D & Dead & 1094 & 11 & 8.86 & 0.67 \\
\hline 7 & El Doradillo & ED_D & Dead & 913 & 10 & 9.32 & 0.78 \\
\hline 10 & Playa Elola & PE_D & Dead & 401 & 8 & 8.00 & 0.71 \\
\hline 11 & Camarones & CA_L & Live & 6255 & 4 & 2.89 & 0.35 \\
\hline 12 & Rada Tilly & RT_D & Dead & 341 & 8 & 7.87 & 0.53 \\
\hline 13 & Caleta Olivia & CO_L & Live & 5329 & 7 & 3.08 & 0.05 \\
\hline 14 & Caleta Olivia & CO_D & Dead & 602 & 7 & 6.86 & 0.71 \\
\hline 15 & Cabo Blanco & CB_D & Dead & 295 & 8 & 8.00 & 0.56 \\
\hline 16 & Puerto Deseado & PuD_D & Dead & 726 & 6 & 5.84 & 0.63 \\
\hline
\end{tabular}


Intertidal vs. subtidal Hard vs. soft substrate (only intertidal)
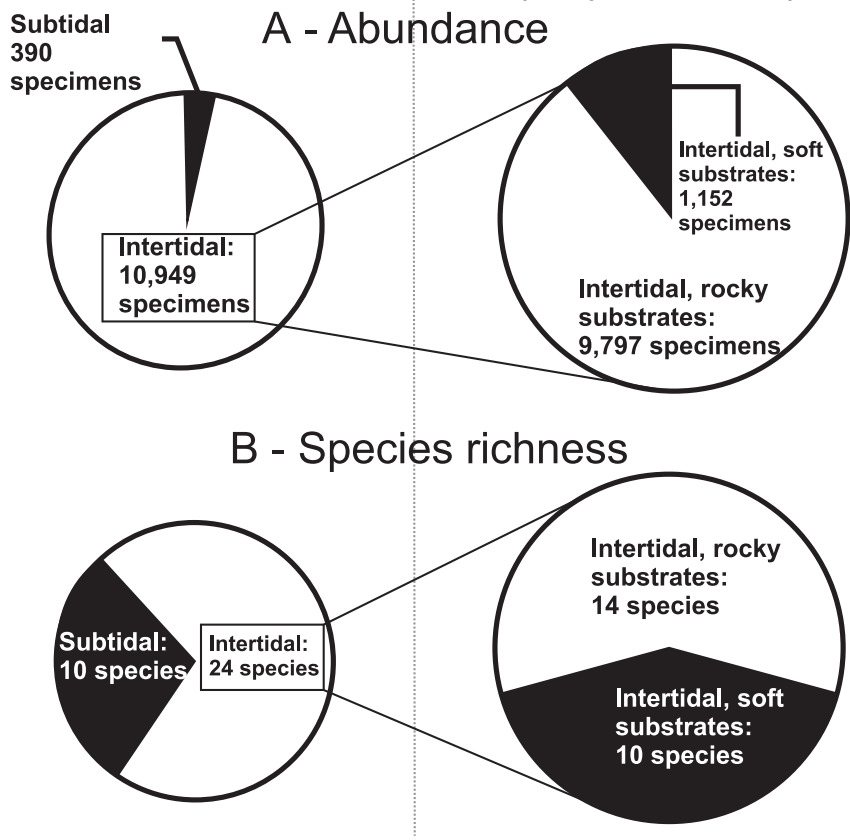

FIG. 3.-Pie charts with details of the distribution of abundance and species richness of death assemblages for data pooled across samples. A) Absolute abundance. B) Species richness. Plots on the left side of the figure differentiate between intertidal and subtidal species while those on the right side indicate distribution of species and specimens between hard and soft substrates of the intertidal belt.

eliminate small specimens from the DAs increasing the average specimen size and/or causing the displacement of size-frequency distribution (SFDs) of DAs to larger sizes. For B. rodriguezii, we compared the size-frequency distribution for Playas Doradas (LA vs. DA), and El Doradillo (DA) vs. Punta Ninfas (LA). For B. purpuratus we compared the size-frequency distribution for El Doradillo (DA) vs. Punta Ninfas
(LA), Playa Elola (DA) vs. Camarones (LA), and Caleta Olivia (LA vs. DA). We measured the maximum linear dimension of the shell (length) in $\mathrm{mm}$ to construct size-frequency distributions. Digital calipers were used for larger mussels, and a microscope micrometer for the smaller ones. A Kolmogorov-Smirnov test was performed to detect overall differences in the distribution of the two samples. Analyses were run with PAST (Hammer et al. 2001)

\section{RESULTS}

\section{Composition of Death Assemblages}

Death assemblages consist of a mix of intertidal and subtidal species inhabiting soft and hard substrates, caused by the mosaic distribution of rocky, muddy, and sandy substrates along the sampling area. Out of the 11,339 specimens from 34 species sampled in the DAs, $86.4 \%(9,797$ specimens, 14 species) inhabit the rocky intertidal belt and were included in the analysis (Fig. 3A, B). From the remaining 13.6\%, 3.4\% (360 individuals, 10 species) belong to subtidal mollusks and $10.2 \%$ correspond to soft-bottom intertidal species (1,152 specimens, 10 species). Therefore, intertidal species accounted for $96.6 \%$ of the specimens in DAs.

\section{Compositional Fidelity}

A total of 37,193 specimens from 15 species were included in the analysis (LA: 27,396; DA: 9,797, Table 3). Of the 15 species, ten were found in the LAs, 14 in DAs, and nine species in both assemblage types. One species found in the LAs was absent in samples from dead shell accumulations (Lasaea sp., see below, Table 4). Conversely, five species detected in DAs were not found in living communities. These dead-only species were one lithophagid mytilid (Lithophaga patagonica), two Calyptraeidae (Crepidula aculeata and $C$. dilatata), the limpet Nacella magellanica, and the snail Tegula patagonica (Table 4). Large mytilids (Aulacomya atra, Mytilus edulis chilensis, and M. edulis platensis) are scarce in living middle intertidal communities, but present or even abundant in DAs (Table 4).

Diversity was consistently higher in DAs than in LAs (Table 3). Species richness was highly variable in the DAs, and consistently low in the LAs (Fig. 4A). PIE evenness index was higher in DAs (Fig. 4B). Rarefaction of species richness to $n=301$ individuals confirms the higher species richness in DAs (Fig. 4C).

TABLE 4.-Species counts per sample.

\begin{tabular}{|c|c|c|c|c|c|c|c|c|c|c|c|c|c|c|c|c|}
\hline Species & LG_L & PM_L & PD_L & PD_D & PL_D & PP_D & ED_D & PM_D & PN_L & PE_D & CA_L & RT_D & CO_L & CO_D & CB_D & PuD_D \\
\hline Aulacomya atra (Molina) & 0 & 0 & 0 & 18 & 68 & 3 & 215 & 38 & 0 & 65 & 1 & 23 & 1 & 142 & 9 & 110 \\
\hline $\begin{array}{l}\text { Brachidontes purpuratus } \\
\quad \text { (Lamarck) }\end{array}$ & 196 & 373 & 2436 & 2 & 885 & 543 & 103 & 438 & 2358 & 192 & 4873 & 38 & 5187 & 227 & 68 & 384 \\
\hline $\begin{array}{l}\text { Brachidontes rodriguezii } \\
\text { d'Orbigny }\end{array}$ & 3694 & 4617 & 982 & 69 & 179 & 231 & 25 & 244 & 314 & 0 & 0 & 0 & 0 & 0 & 0 & 0 \\
\hline Crepidula aculeata (Gmelin) & 0 & 0 & 0 & 4 & 1 & 0 & 0 & 1 & 0 & 0 & 0 & 0 & 0 & 0 & 0 & 0 \\
\hline Crepidula dilatata Lamarck & 0 & 0 & 0 & 17 & 15 & 1 & 41 & 71 & 0 & 12 & 0 & 28 & 0 & 8 & 13 & 0 \\
\hline $\begin{array}{l}\text { Fissurella sp. } \\
\text { Lithophaga patagonica }\end{array}$ & 0 & 0 & 0 & 26 & 50 & 5 & 13 & 1 & 1 & 0 & 0 & 0 & 0 & 0 & 1 & 0 \\
\hline (d'Orbigny) & 0 & 0 & 0 & 0 & 0 & 1 & 1 & 3 & 0 & 0 & 0 & 0 & 0 & 0 & 0 & 0 \\
\hline $\begin{array}{l}\text { Mytilus edulis chilensis Hupé } \\
\text { Mytilus edulis platensis }\end{array}$ & 0 & 0 & 0 & 0 & 0 & 7 & 0 & 0 & 1 & 5 & 0 & 229 & 1 & 7 & 184 & 184 \\
\hline $\begin{array}{l}\text { d'Orbigny } \\
\text { Nacella (P.) magellanica }\end{array}$ & 5 & 106 & 4 & 10 & 93 & 25 & 17 & 30 & 0 & 0 & 0 & 0 & 0 & 0 & 0 & 0 \\
\hline (Gmelin) & 0 & 0 & 0 & 11 & 67 & 0 & 0 & 0 & 0 & 48 & 0 & 9 & 0 & 182 & 10 & 38 \\
\hline Pareuthria plumbea (Philippi) & 0 & 0 & 0 & 0 & 0 & 0 & 0 & 0 & 0 & 8 & 0 & 0 & 1 & 3 & 3 & 6 \\
\hline $\begin{array}{l}\text { Siphonaria lessonii } \\
\text { (Blainville) }\end{array}$ & 8 & 52 & 116 & 21 & 145 & 191 & 174 & 180 & 1 & 53 & 37 & 2 & 112 & 0 & 0 & 0 \\
\hline Tegula patagonica d'Orbigny & 0 & 0 & 0 & 406 & 129 & 69 & 307 & 1885 & 0 & 0 & 0 & 1 & 0 & 0 & 0 & 0 \\
\hline Trophon geversianus (Pallas) & 0 & 1 & 1 & 50 & 146 & 18 & 17 & 122 & 7 & 18 & 0 & 11 & 3 & 33 & 7 & 4 \\
\hline Lasaea sp. & 0 & 424 & 25 & 0 & 0 & 0 & 0 & 0 & 90 & 0 & 1344 & 0 & 24 & 0 & 0 & 0 \\
\hline
\end{tabular}



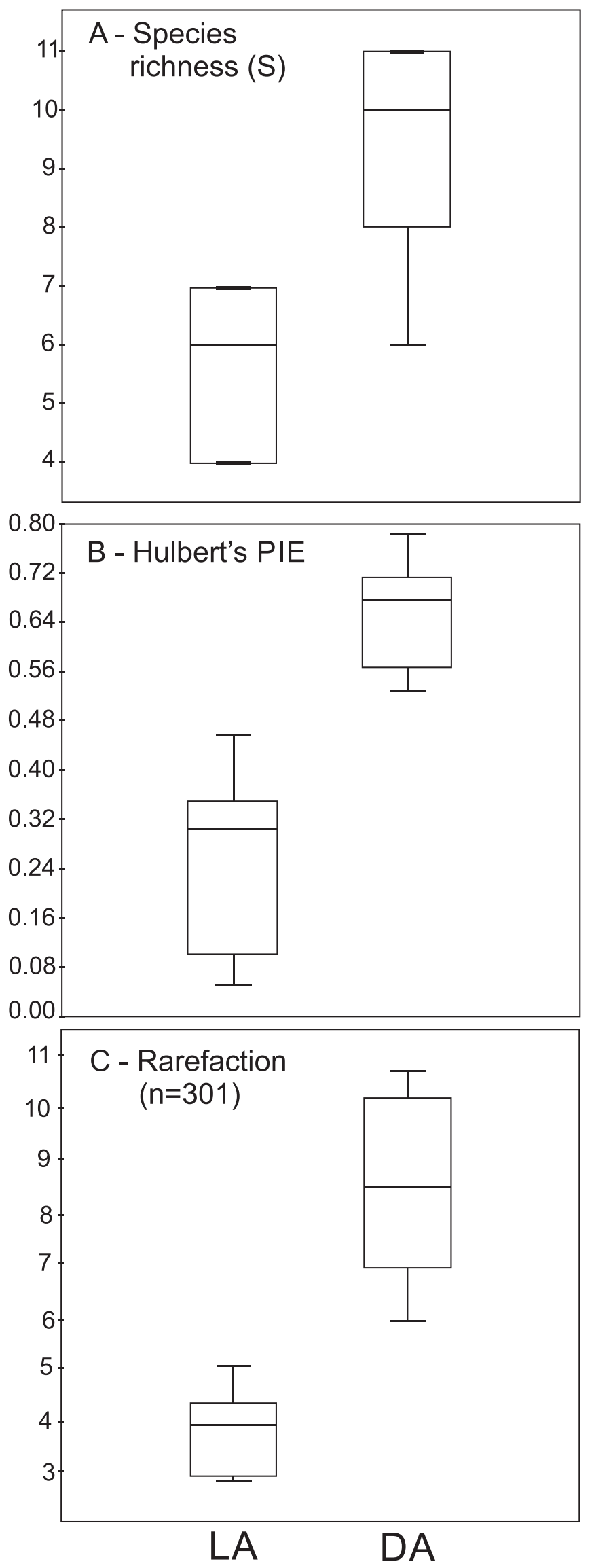

The NMDS showed that both latitude (which correlates with biogeographic affinity of localities) and assemblage type (LA versus DA) discriminate assemblages in a multivariate space (Fig. 5A, B). DAs belonging to the Argentine-Magellanic Transition Zone (localities 4 to 8) cluster together, and are separated from southern Magellanic localities (localities 10, 12, and 14-16). Living communities show a latitudinal arrangement along the $y$-axis of the NMDS plot (with equatorward localities on the top; Fig. 5A, B). Although DAs do not show the latitudinal signature within the two biogeographical provinces, they still clearly segregate the Transition Zone and Magellanic Province. PERMANOVA tests confirm this observation: DAs from the Transition Zone differ significantly from those sampled in the Magellanic Province $(\mathrm{F}=$ 5.47; $\mathrm{p}=0.009$ ). The composition of LAs did not significantly differ between the Transition Zone and the Magellanic Province $(F=2.75 ; p=$ 0.133 ). However, this result could be an artifact of a small number of samples, with only two LAs in the Magellanic Province.

Species composition and abundance were significantly different between LAs and DAs for the full matrix $(F=4.38 ; \mathrm{p}=0.002)$ and for the samples from the Transition Zone between provinces $(F=4.50 ; p$ $=0.013)$. Within the Magellanic Province, species composition was not significantly different $(F=4.20 ; p=0.096)$, although this result could be related to the small number of LAs in the Magellanic Province $(n=2)$. Comparison of species abundance between LAs and DAs from closely spaced localities at Playas Doradas (within the Transition Zone) show overrepresentation of Tegula patagonica and underrepresentation of Lasaea sp. in DAs (Fig. 6). In the cases of Camarones/Playa Elola and Caleta Olivia (in the Magellanic Province), Aulacomya atra and Nacella magellanica are overrepresented and in both cases Lasaea sp. is underrepresented in DAs (Fig. 6). In turn, comparisons within provinces show that Tegula patagonica is highly overrepresented in DAs in the Transition Zone while Lasaea sp. is underrepresented (Fig. 7). Within the Magellanic Province, Mytilus edulis chilensis, Aulacomya atra, and Nacella magellanica are overrepresented while Lasaea sp. is underrepresented in DAs (Fig. 7).

\section{Size Fidelity}

Dead shells of $B$. purpuratus and B. rodriguezii are larger than shells from living communities ( $\mathrm{p}<0.0001$ in all five comparisons; Fig. 8A-E, Table 5). Size-frequency distributions of living mussels show a bimodal or multimodal distribution (frequently with high abundance of specimens smaller than $5 \mathrm{~mm}$ ), while dead shells show a unimodal distribution with modes at $\sim 15-20 \mathrm{~mm}$ (Fig. 8A-E). In addition, measurements from DAs have consistently lower variation than those taken from living communities (Table 5).

\section{DISCUSSION}

The results of our analyses show a general agreement with previous studies restricted to single habitats, mainly performed in subtidal and soft-bottom environments: $90 \%$ of the living species are found dead in the same study area, and $64 \%$ of the dead species are found alive in the same area. Summarizing these live-dead indices from various marine environments, Kidwell and Bosence (1991) showed that the live species represented in DAs range from $83 \%$ (intertidal) to $95 \%$ (coastal subtidal), while dead species found in living communities range from 33\% (coastal subtidal) to $54 \%$ (intertidal).

FIG. 4.-Boxplots show that diversity indices are higher in DAs than LAs. A) Species richness (S). B) Evenness index (PIE). C) Species richness estimated by rarefaction. Boxes range from first to third quartile. Whiskers represent minimum and maximum values. LA: life assemblages. DA: death assemblages. 

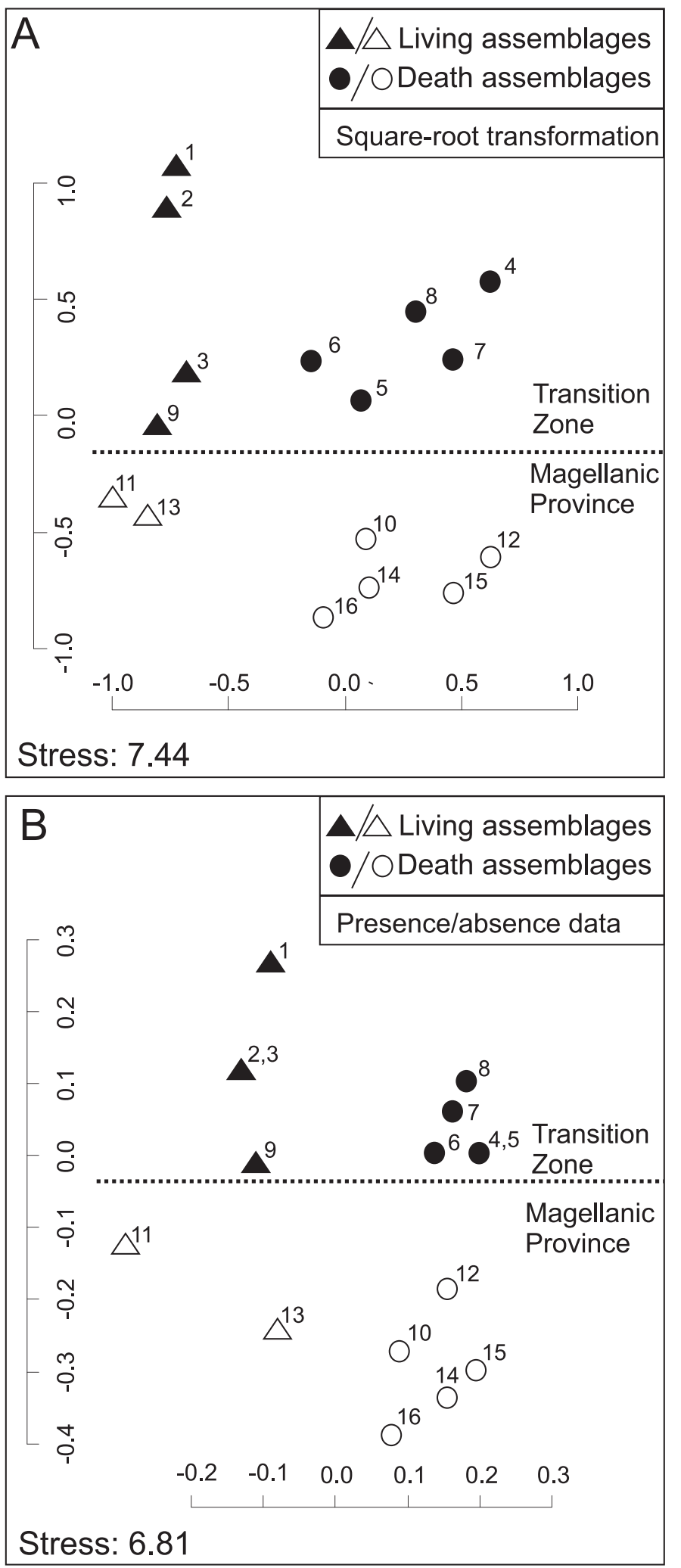

FIG. 5.-Two-dimensional NMDS plots show segregation between two provinces for both living and death assemblages but also a consistent segregation between living and death assemblages. A) Square-root transformation after standardization to percentages. B) Presence-absence data. Axes were rotated to place samples in a latitudinal order. Symbols: triangles = living assemblages; circles $=$ death assemblages; filled symbols $=$ Argentine-Magellanic Transition Zone; empty symbols $=$ Magellanic Biogeographic Province.
One of the factors affecting the magnitude of live-dead agreements observed in this study could be the variability in the proportion of soft and hard substrates among localities and in the detectability of some species in LAs due to their vagile life habits. For instance, Puerto Madryn is dominated by sandy and muddy soft substrates (Table 1), which correlates with the high abundance of Tegula patagonica in DAs (which is absent in LAs). Similarly, the muricid Trophon geversianus is normally found in the lower intertidal to subtidal, and in our study it is more abundant in DAs than in LAs. Both species are vagile and are thus able to escape subaerial exposure or hide during low tides, decreasing their probability of being sampled in the LAs. Another species with particular life habits is Lithophaga patagonica, a bioeroder that inhabits bottle-shaped rock borings. This species is present in DAs but absent in living communities, most likely due to the low detectability caused by its cryptic life habit. A similar factor also affects the low detectability of cryptic species in LAs in hard-bottom habitats in coral reefs reported by Zuschin et al. (2000) and in offshore reefs dominated by coralline algae and Posidonia oceanica reported by Albano and Sabelli (2011). Also, DAs were not sieved and this fact could have added an artificial bias against small specimens, even when sampling design was developed to reduce the drawback. Finally, the possible effect of human impact on communities (Kidwell 2013) was not considered. These factors should be assessed in future studies.

\section{Origin of Intertidal Death Assemblages}

Death assemblages accumulated above the intertidal belt in Patagonian rocky shores include a mix of shallow subtidal to upper intertidal species that inhabit both hard and soft substrates. However, most specimens belong to species living in the intertidal belt $(96.6 \%)$, and more than four fifths of them are hard-substrate dwellers (86.4\%) (Fig. 3). These proportions suggest that the supratidal high-water mark is a good area to obtain samples from intertidal species on Patagonian shores; at the same time, our results indicate that the bathymetric mixing of faunas from intertidal and subtidal settings is minor, affecting only $3.4 \%$ of the specimens.

The formation of intertidal DAs can be explained as strandings caused by storms and high tides that move shells and live specimens from sublittoral bottoms to the swash zone and above (López et al. 2008). In our case, both storms and high tides can explain the genesis of DAs. We also observed Mytilus shells rolling on the beach due to strong winds, suggesting that winds can also aggregate shells into DAs.

\section{Size-Associated Taphonomic Biases}

Despite the general agreement between LAs and DAs, multivariate analyses show that DAs and LAs are compositionally segregated at all latitudes. Species that are underrepresented in DAs tend to be smaller. The absence of Lasaea sp. in DAs is one of the most striking examples. Lasaea sp. represents $7 \%$ of the abundance of the pooled samples from living communities, reaching as much as $21.5 \%$ in Puerto Madryn (Table 4). However, this species is completely absent from all DAs (Table 4). It is likely that individuals from this species could have been destroyed or transported away because they are $3 \mathrm{~mm}$ long and very thin and live attached to mussels by byssi (Forcelli 2000, and observations of the authors). Transportation by water is possible because minute valves are washed away during high tides, kept in suspension, and finally deposited on deeper, calmer bottoms (Fürsich 1990; Valentine et al. 2006; and observations of the authors). The strong winds in Patagonia are also able to remove these shells, and cause the small-sized mussels $(<5 \mathrm{~mm})$ to be transported by the wind. This interference is consistent with the observation that body size is one of the main factors explaining the absence of living species in the fossil record (Valentine et al. 2006).

All size-frequency comparisons for Brachidontes species show that DAs are enriched in shells larger than $7 \mathrm{~mm}$ with respect to LAs (Fig. 8A-E), 


\section{Living assemblages}

\section{Death assemblages}
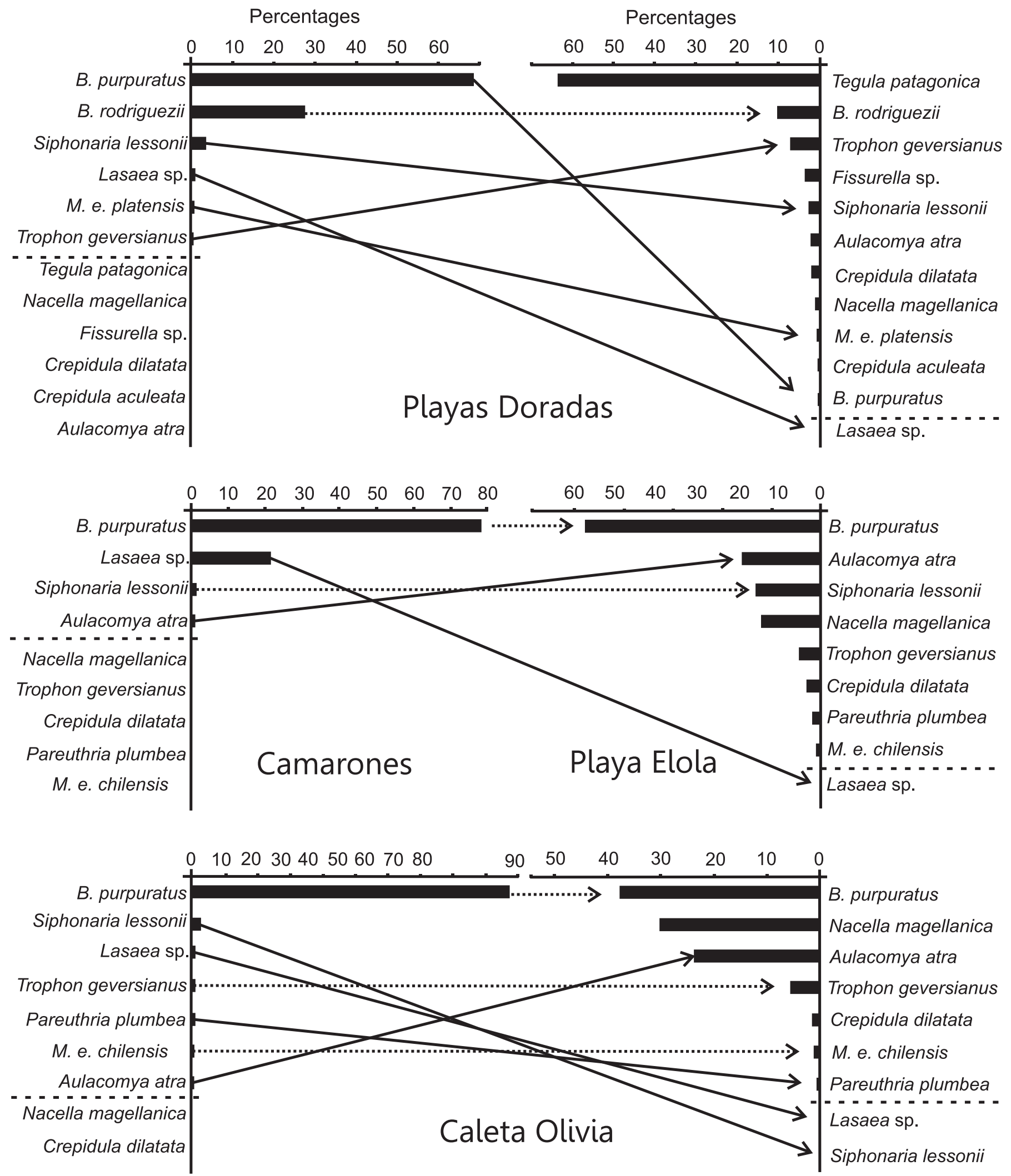

FIG. 6.-Bar plots with species-level composition of the living and death assemblages. Dissimilarities between LAs and DAs are reflected in differences in rank order and abundance of the taxa. 


\section{Living assemblages}

\section{Death assemblages}
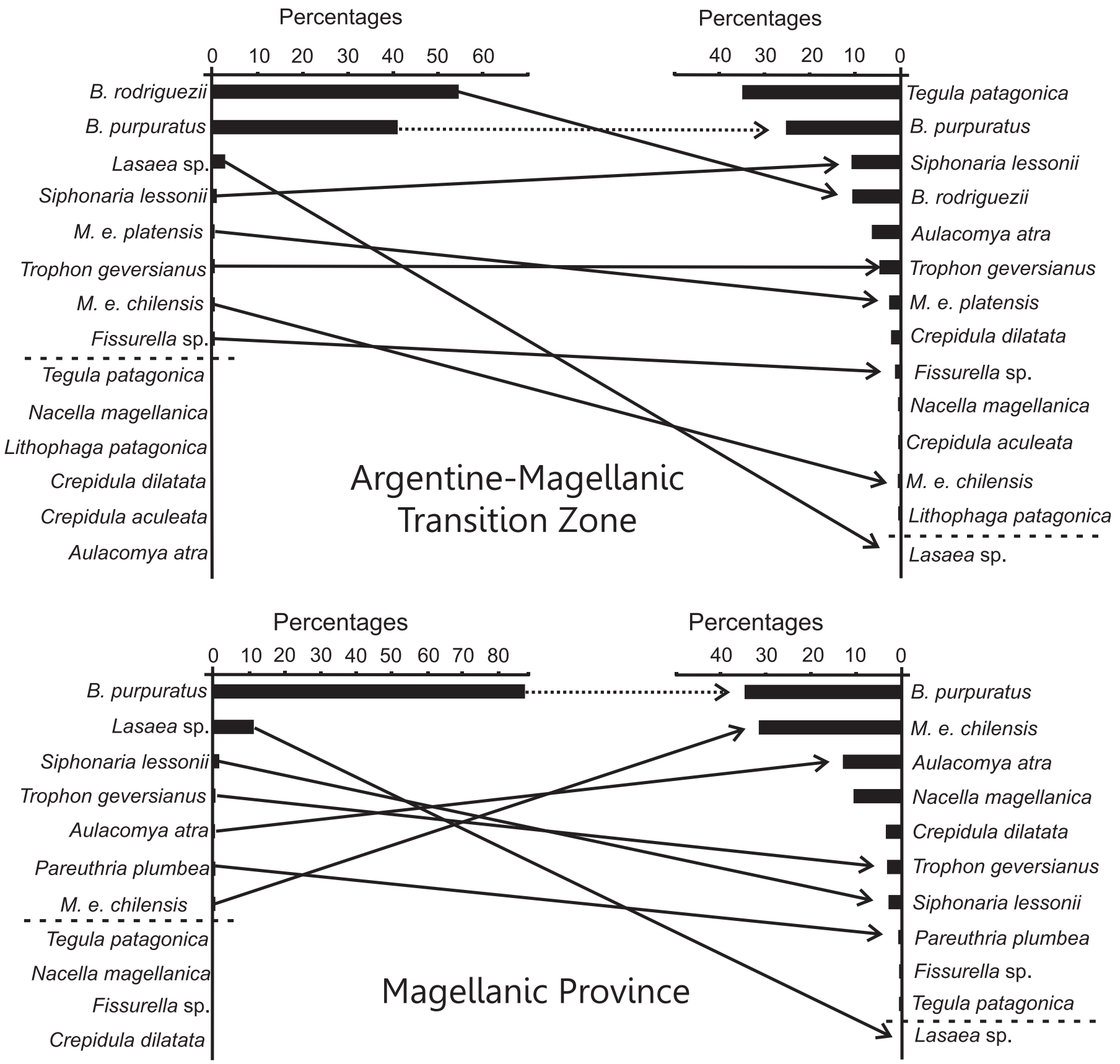

Fig. 7.-Bar plots with species-level composition of the living and death assemblages for data pooled across samples per biogeographic region. Dissimilarities between LAs and DAs are reflected in differences in rank order and abundance of the taxa.

whereas juvenile individuals are present in all size-frequency distributions in LAs (Fig. 8). Also, histograms indicate that the rather complicated bimodal to multimodal distribution in LAs becomes unimodal (Fig. 8AD) or platykurtic in DAs (Fig. 8E).

Therefore, the main bias between the LAs and DAs is probably size related. All samples come from communities living in the middle intertidal, and are thus subject to high water flows during high tides, which could be regulating the transport process toward the upper intertidal, at least for the small-sized shells. In the absence of burial in rocky intertidal habitats and under reduced burial rates in mixed-bottom intertidal environments, juvenile specimens are also more likely destroyed than large-sized and thicker adults (Tomašových 2004).

The interpretation of a size-related bias is also supported by the observation that Brachidontes species are less frequent in DAs than in LAs. Mean per-sample percentages show that these small-sized mytilids represent almost $93 \%$ of the LAs and only $44 \%$ of the DAs. This underrepresentation of small-sized mytilids in DAs is consistent within each biogeographic unit. Therefore, the decrease in dominance of Brachidontes species could be 

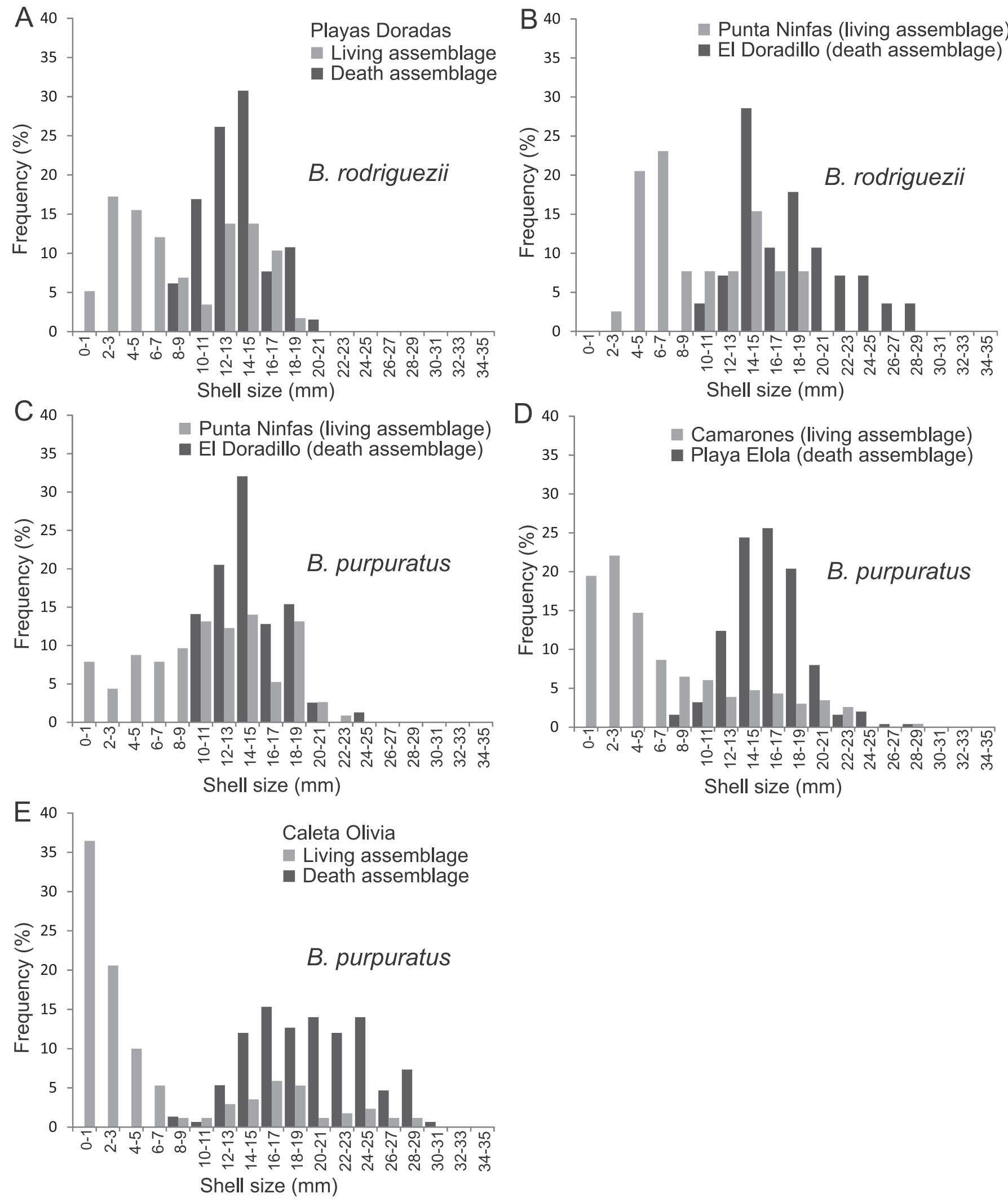

FIG. 8. - Size-frequency distributions of death assemblages are characterized by higher proportions of large-sized specimens with respect to specimens from living communities for Brachidontes rodriguezii and B. purpuratus at different localities. A) Brachidontes rodriguezii, Playas Doradas (LA vs. DA). B) Brachidontes rodriguezii, El Doradillo (DA) vs. Punta Ninfas (LA). C) Brachidontes purpuratus, El Doradillo (DA) vs. Punta Ninfas (LA). D) Brachidontes purpuratus, Playa Elola (DA) vs. Camarones (LA). E) Brachidontes purpuratus, Caleta Olivia (LA vs. DA). Symbols: black = specimens from death assemblages; gray $=$ specimens from life assemblages. 


\section{Death assemblages}

Living assemblages

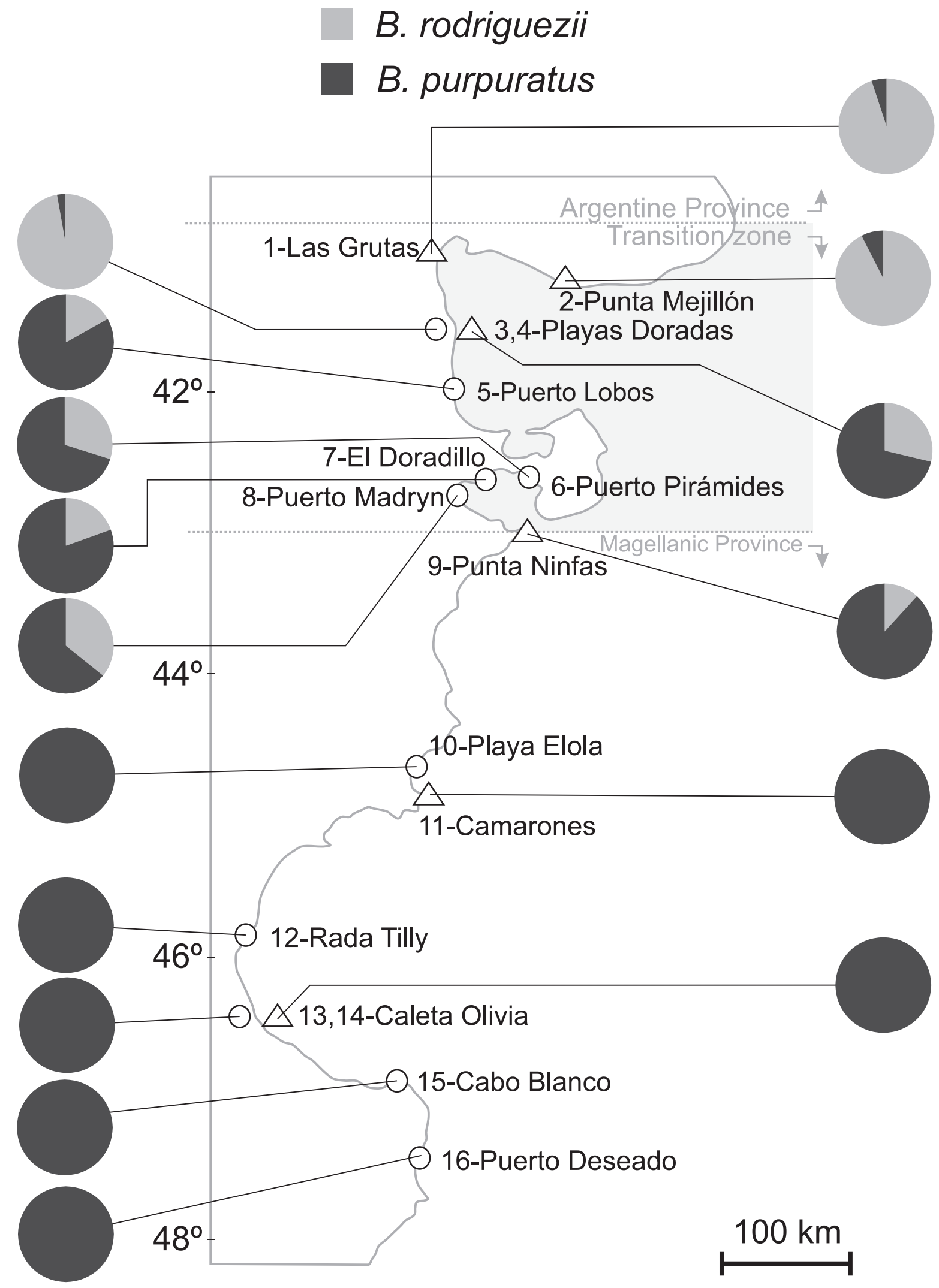


TABLE 5.-Descriptive statistics of the sizes of Brachidontes rodriguezii and B. purpuratus, separated by locality and type of sample. Abbreviations: $N=$ number of samples; $C V=$ coefficient of variation.

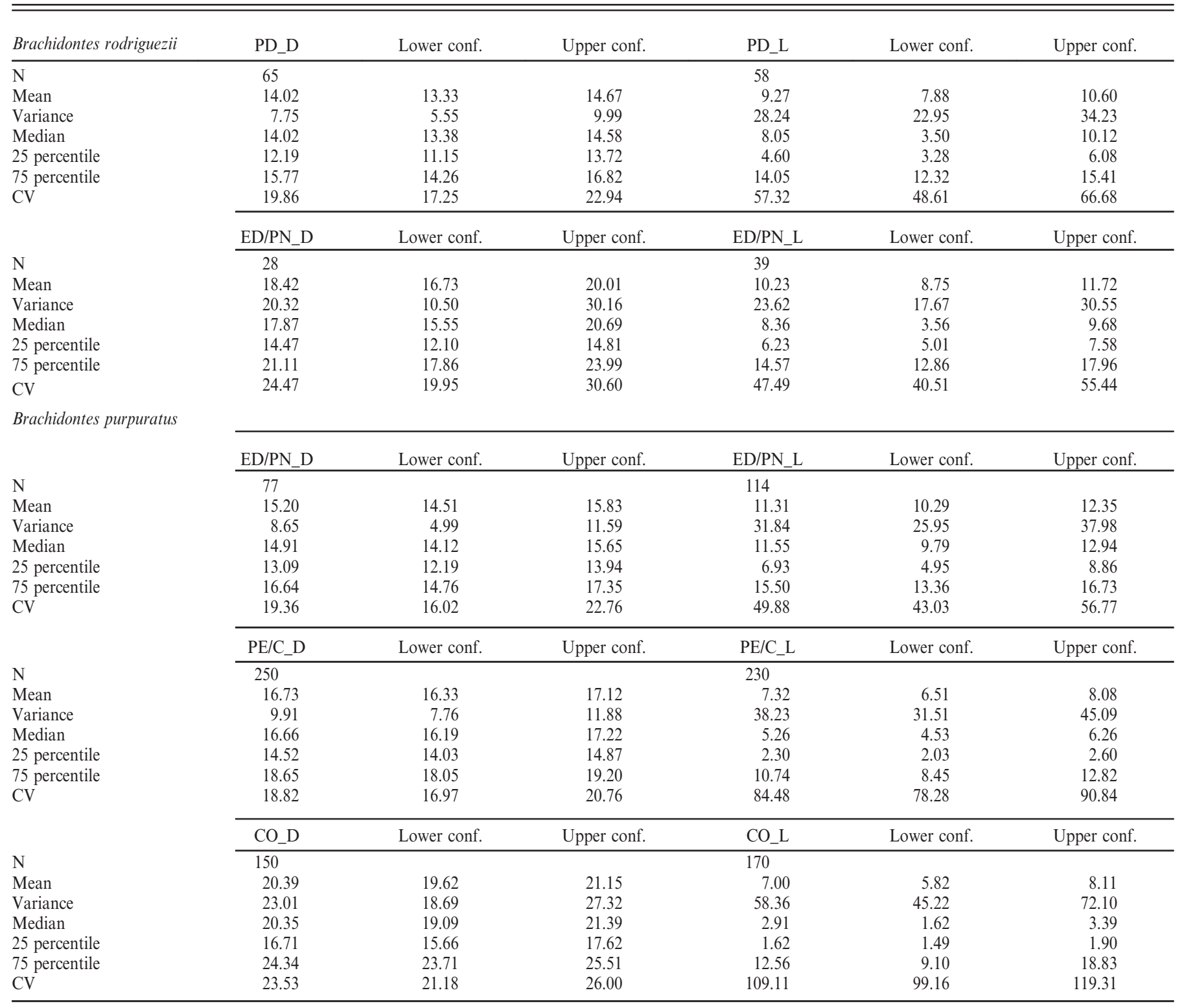

explained by the effect of destruction and transportation out of the habitat. Also, this decrease could alternatively be explained by the effect of time coarsening: DAs may combine the abundance structure of communities that changed dominant species through time (Tomašových and Kidwell 2010). Methodological differences in sampling collection between LAs and DAs might have partly contributed to the differences.

\section{Effects of Temporal and Spatial Averaging on Species Diversity}

The DAs studied here are inferred to be time averaged. A consequence of this process is the mixing of several generations in the same environment (Fürsich and Aberhan 1990; Tomašových and Kidwell 2009; Kidwell and Tomašových 2013). Higher levels of species richness and evenness coincide with the prediction of increased diversity in DAs (Fürsich and Aberhan 1990; Tomašových and Kidwell 2010; Kidwell and Tomašových 2013). The reduction in dominance and enrichment in rare species has also been identified as a likely result of time averaging because as the time during which a DA receives hard parts increases, the probability of incorporation of new species by immigration of nearby locations and/or the occurrences of changes in habitat conditions (e.g., varying proportions of soft- and hard-bottom patches in intertidal environments) also increases (Fürsich and Aberhan 1990; Tomašových

FIG. 9.- Proportions of Brachidontes rodriguezii (light gray) and B. purpuratus (dark gray) across the studied area show that both living and death assemblages capture the latitudinal gradients in their abundance. Symbols: circles $=$ death assemblages; triangles $=$ living assemblages . 
and Kidwell 2010; Kidwell and Tomašových 2013), although similar effects can be produced by spatial mixing.

Calyptraeid species, true limpets, and large mytilids, which are absent or scarce in LAs but present and in some cases abundant in DAs, are typical of lower intertidal to subtidal environments and rarely occur alive in middle intertidal rocky habitats (Olivier et al. 1966b; Zaixso and Pastor 1977; Bertness et al. 2006; Silliman et al. 2011). Similarly, the mismatch in abundance of the snail Tegula patagonica, which reaches high abundance in DAs (1,885 individuals in Puerto Madryn) but does not occur in LAs (and is considered a rare inhabitant of the midintertidal rocky habitat; Sánchez and Zaixso 1995; Wieters et al. 2012), is another example of a species that is rare in the LAs and becomes common in the DAs. All these species that are absent or rare in LAs, but present and sometimes abundant in DAs, correspond to rare inhabitants of the middle intertidal that were incorporated in disproportionately higher abundance due to the temporal coarsening or spatial mixing of these samples.

\section{Spatial Variation in Composition at Biogeographic Scales}

The species composition and abundance of LAs vary along a latitudinal gradient (Fig. 5), following a poleward decrease in seawater temperature. On one hand, this latitudinal pattern is not present among DAs within the same biogeographic unit. On the other hand, compositional differences between the Transition Zone and Magellanic Province are still clearly captured by DAs. The latitudinal gradient captured by LAs coincides with a gradual replacement of Brachidontes rodriguezii (species characteristic of the Argentine Biogeographic Province) by B. purpuratus (typical of the Magellanic Biogeographic Province) (Fig. 9). In contrast, DAs in the Transition Zone are characterized by a relatively stable percentage of both Brachidontes species (sites 5 to 8), with the exception of Playas Doradas which has a small proportion of $B$. purpuratus (Fig. 9). Spearman rank correlation between latitude and logarithm of the ratio of $B$. rodriguezii to $B$. purpuratus in the Transition Zone showed a negative correlation in the case of LAs ( $r s=-1, p=0.083$ ) that is however nonsignificant, and a weak and nonsignificant correlation in the case of the DAs ( $\mathrm{rs}=-0.1$, $\mathrm{p}=0.783$ ). Mussel beds in the Transition Zone show high heterogeneity (patchy distribution) with respect to the proportion of both Brachidontes species (Arribas et al. 2013), a pattern that does not help in explaining the lack of gradual replacement in DAs. However, the increase in Brachidontes rodriguezii from the Magellanic toward the Transition zones contributes to the between-province separation in the DAs. The temporal changes in community structure of LAs at the contact between the Magellanic and Argentine Biogeographic Provinces likely produced a mix of shells from both provinces with variable proportions, but was not enough to homogenize of the two biogeographic zones

Boretto et al. (2013) detected temporal changes in the molluscan species composition during the Quaternary along the Puerto Lobos coastal area. These authors compared the Pleistocene, Holocene, and Modern fauna. The presence of Tegula atra and Mactra patagonica in Pleistocene sediments indicated a greater proportion of taxa typical from the coldwater Magellanic Province; however, during the Holocene the most typical element in the area was Glycymeris longior, characteristic of the Argentinean Province. During the late Holocene, this study area also recorded a faunal shift in which species belonging to the Magellanic Province displaced the fauna of the Argentinean Province to the north, probably in coincidence with the Little Ice Age.

The presence of $B$. rodriguezii in the study area can be traced back to the Miocene Paraná and Madryn Formations of Argentina and Uruguay (del Río and Martínez 1998). Brachidontes purpuratus, in turn, seems to be a more recent immigrant from the southeastern Pacific (during
Plio-Pleistocene transition) based on genetic, morphological, and geological evidence (Trovant et al. 2013, 2015). Trovant et al. (2015) suggest that the distribution of B. purpuratus is related to latitudinal gradients in the sea surface temperature (B. purpuratus favors SST below $13{ }^{\circ} \mathrm{C}$ ), although its expansion northward is probably blocked by the high densities of B. rodriguezii. In this way, climatic fluctuations in the last few hundreds or thousands or years may have pushed the Transition Zone northward or southward and then blurred the pattern of gradual replacement between species in the DAs. Possible temporal changes in the distribution of these species may also help explain the low association in rank abundance between adjacent localities observed in this study (Fig. 6, upper part). This observation is reflected in the statistically significant differences between LAs and DAs in the Transition Zone (seen in PERMANOVA results).

This result coincides with those of Tomašových and Kidwell (2009) where the variability in species composition among DAs is lower than among LAs for both abundance and presence-absence data. It is possible that the time involved in the formation of DAs caused mixing in the species composition of the communities due to ecological succession, immigration, extinction, or due to stochastic and environmental changes (Fürsich and Aberhan 1990; Bennington 2003; Tomašových and Kidwell 2009), leading to the lack of latitudinal gradient in composition of DAs within provinces. However, the possible homogenization generated by those mechanisms was not sufficient to reduce differences between the Argentine-Magellanic Transition Zone and the Magellanic Province.

\section{CONCLUSIONS}

1. Death assemblages from intertidal rocky shores on the Atlantic coast of Patagonia show a moderate agreement in species composition and abundance between DAs sampled in mixed-bottom intertidal environments and living mussel communities inhabiting nondepositional rocky bottoms in the same region. Even when spatial variation within the two provinces seems to be homogenized (probably due to the averaging of successive communities affected by fluctuating temporal changes in the biota), differences between the Argentine-Magellanic Transition Zone and the Magellanic Province are clearly detected in DAs. Our results reinforce the usefulness of death assemblages as proxies of living communities at regional spatial scale (Kidwell and Tomašových 2013) and justify the reliability of studies based on them (e.g., Gordillo and Archuby 2012, 2014; Martinelli et al. 2013).

2. Death assemblages have higher diversity than living assemblages, probably due to their time-averaged nature (and spatial mixing).

3. The main taphonomic distortion between LAs and DAs is the lower abundance of small species and the underrepresentation of smallest specimens (less than $8 \mathrm{~mm}$ ). This bias is probably caused by differential transport and destruction by waves, currents, and wind. Another source of live-dead mismatch seems to be related to reduced detectability of vagile epifaunal species and boring species in LAs.

\section{ACKNOWLEDGMENTS}

The authors greatly appreciate comments and suggestions by Carrie Tyler and an anonymous reviewer that significantly improved the manuscript. The associate editor, Adam Tomašových, also provided valuable insights and very helpful advice. A. Puig (Museo Argentino de Ciencias Naturales, Buenos Aires) facilitated use of their laboratory of Freshwater Plankton and Benthos to MA to process material. Living assemblages considered in this work were collected during the course of the doctoral thesis of MA. Death assemblages were collected during fieldwork funded by CONICET (PIP 114200801-00260) to SG. 


\section{REFERENCES}

Adami, M. L., 2008, Efectos de la herbivoría de la lapa Siphonaria lessoni Blainville 1924 (Gastropoda) sobre la comunidad asociada a Brachidontes rodriguezii (d'Orbigny 1846) (Bivalvia): Revista Museo Argentino de Ciencias Naturales, v. 10 (2), p. 309-317.

Adami, M.L., Tablado, A., And López Gappa, J.J., 2004, Spatial and temporal variability in intertidal assemblages dominated by the mussel Brachidontes rodriguezii (d'Orbigny, 1846): Hydrobiologia, v. 520, p. 49-59, doi: 10.1023/B:HYDR. 0000027724.42811 .19 .

Adami, M.L., Tablado, A., and Sodor, M.A., 2008, Population dynamics of the intertidal mytilid Brachidontes rodriguezii (Bivalvia) on a rocky shore: Thalassas, v. 24, p. 19-25.

Adami, M., Pastorino, G., and Orensanz, J.M., 2013, Phenotypic differentiation of ecologically significant Brachidontes species co-occurring in intertidal mussel beds from the southwestern Atlantic: Malacologia, v. 56, p. 59-67, doi: 10.4002/040.056.0204.

Albano, P.G., And Sabelli, B., 2011, Comparison between death and living molluscs assemblages in a Mediterranean infralittoral off-shore reef: Palaeogeography, Palaeoclimatology, Palaeoecology, v. 310, p. 206-215. doi: 10.1016/j.palaeo.2011.07.012.

Aldea C., And Troncoso, J.S., 2010, Remarks on the genus Trophon (s.1.) Montfort, 1810 (Mollusca: Gastropoda: Muricidae) in the Southern Ocean and adjacent areas: Thalassas, v. 26, p. 47-73.

Arribas, L.P., Bagur, M., Klein, E., Penchaszadeh, P.E., and Palomo, M.G., 2013, Geographic distribution of two mussel species and associated assemblages along the northern Argentinean coast: Aquatic Biology, v. 18, p. 91-103, doi: 10.3354/ab00495.

Balech, E., AND Ehrlich, M.D., 2008, Esquema biogeográfico del mar Argentino: Revista de Investigación y Desarrollo Pesquero, v. 19, p. 45-75.

Bennington, J.B., 2003, Trascending patchiness in the comparative analysis of paleocommunities: a test case from the Upper Cretaceous of New Jersey: PALAIOS, v. 18 , p. 22-33, doi: $10.1669 / 0883-1351$.

Bernard, F.R., 1983, Catalogue of the living Bivalvia of the eastern Pacific Ocean: Bering Strait to Cape Horn: Canadian Special Publication of Fisheries and Aquatic Sciences. v. 61, p. 1-102.

Bertness, M.D., Crain, C.M., Silliman, B.R., Bazterrica, M.C., Reyna, M.V., Hidalgo, F., and Farina, J.K., 2006, The communities structure of western Atlantic Patagonian Rocky Shores: Ecological Monographs, v. 76, p. 439-460, doi: 10. 1890/0012-9615.

Bigatti, G., Marzinelli, E.M., and Penchaszadeh, P.E., 2008, Seasonal reproduction and sexual maturity in Odontocymbiola magellanica (Neogastropoda, Volutidae): Invertebrate Biology, v. 127, no. 3, p. 314-326, doi: 10.1111/j.1744-7410.2008.00139.x.

Boretto, G., Gordillo, S., Colombo, F., Cioccale, M., and Fucks, E.E., 2013, Multiproxy evidence of late Quaternary environmental changes in the coastal area of Puerto Lobos (northern Patagonia, Argentina): Quaternary International, v. 305, v. 188-205, doi: 10.1016/j.quaint.2013.02.017.

Camacho, H., 1979, Descripción geológica de la hoja 47h-48g, Bahía Camarones. Provincia de Chubut: Servicio Geológico Nacional, Argentina, Boletín, v. 153, p. 1-29.

Charó, M.P., Gordillo, S., ANd Fucks, E.E., 2013, Paleoecology significance of late Quaternary molluscan faunas of the Bahía San Blas area, Argentina: Quaternary International, v. 301, p. 135-149, doi: 10.1016/j.quaint.2012.12.019.

Charó, M.P., Gordillo, S., Fucks, E.E., And Giaconi, L.M., 2014, Late Quaternary molluscs from the northern San Matías Gulf (Northern Patagonia, Argentina), southwestern Atlantic: faunistic changes and paleoenvironmental interpretation: Quaternary International, p. 1-22, doi: 10.1016/j.quaint.2013.12.044.

Clapperton, C.M., 1993, Quaternary Geology and Geomorphology of South America: Amsterdam, Elsevier, 768 p.

Clarke, K.R., 1993, Non-parametric multivariate analyses of changes in community structure: Australian Journal of Ecology, v. 18, p. 117-143, doi: 10.1111/j.1442-9993. 1993.tb00438.x.

Clarke, K.R., and Warwick, R.M., 2001, Change in Marine Communities: An Approach to Statistical Analysis and Interpretation, 2nd ed.: PRIMER-E, Plymouth, UK, $175 \mathrm{p}$.

Clarke, K.R., Somerfield, P.J., and Chapman, M.G., 2006, On resemblance measures for ecological studies, including taxonomic dissimilarities and a zero-adjusted BrayCurtis coefficient for denuded assemblages: Journal of Experimental Marine Biology and Ecology, v. 330, p. 55-80, doi: 10.1016/j.jembe.2005.12.017.

Commito, J.A., And Rusignuolo, B.R., 2000, Structural complexity in mussel beds: the fractal geometry of surface topography: Journal of Experimental Marine Biology and Ecology, v. 255, p. 133-152, doi: 10.1016/S0022-0981(00)00285-9.

Cuevas, J.M., Martin, J.P., and Bastida, R., 2006, Benthic community changes in a Patagonian intertidal: a forty years later comparison: Thalassas, v. 22, p. 29-37.

DADON, J.R., 2005, Changes in the intertidal community structure after a mass mortality event in sandy beaches of Argentina: Contributions to Zoology, v. 74, no. 1/2, http:// www.ctoz.nl/vol74/nr01/a02.

De Francesco, C.G., Tietze, E., And Cristini, P.A., 2013, Mollusk successions of Holocene shallow-lake deposits from the southeastern Pampa plain, Argentina: PALAIOS, v. 28, p. 851-862, doi: 10.2110/palo.2013.100.

del Río, C., and Martínez, S.A., 1998, Moluscos marinos miocenos de la Argentina y del Uruguay: Monografías de la Academia Nacional de Ciencias Exactas, Físicas y Naturales, v. 15, 95 p.

Erthal, F., Kotzian, C.B., and Simoes, M.G., 2011, Fidelity of molluscan assemblages from the Touro Passo Formation (Pleistocene-Holocene), Southern Brazil: taphonomy as a tool for discovering natural baselines for freshwater communities: PALAIOS, v. 26, p. 433-446, doi: 10.2110/palo.2010.p10-145r.
Feser, K.M., AND Miller, A.I., 2014, Temporal dynamics of shallow seagrassassociated molluscan assemblages in St. Croix, US Virgin Islands: toward the calibration of taphonomic inertia: PALAIOS, v. 29, no. 5, p. 218-230, doi: 10 2110/palo.2013.103

Fiori, S.M., AND CAzzAniga, N.J., 1999, Mass mortality of the yellow clam, Mesodesma mactroides (Bivalvia: Mactracea) in Monte Hermoso beach, Argentina: Biological Conservation, v. 89, p. 305-309, doi: 10.1016/S0006-3207(98)00151-7.

Forcelli, D.O., 2000, Moluscos Magallánicos: Buenos Aires, Vázquez Mazzini Editores, 200 p.

FürsICH, F.T., 1978, The influence of faunal condensation and mixing on the preservation of fossil benthic communities: Lethaia, v. 11, p. 243-250, doi: 10.1111/j. 1502-3931.1978.tb01231.x.

FüRsICH, F.T., 1990, Fossil concentrations and life and death assemblages, in Briggs, D.E.G., and Crowther, P.R., eds., Palaeobiology. A Synthesis: : Oxford, UK, Blackwell Scientific Publications, , p. p. 235-239.

FürsICH, F.T., 1995, Shell concentrations: Eclogae geologicae Helvetiae, v. 88, p. 643 655, doi: $10.5169 /$ seals-167692.

FÜRsich, F.T., AND ABERHAN, M., 1990, Significance of time-averaging for paleocomunity analysis: Lethaia, v. 23, p. 143-152, doi: 10.1111/j.1502-3931.1990.tb01355.x.

Fürsich, F.T., AND Flessa, K.W., 1987, Taphonomy of tidal flat molluscs in the Northern Gulf of California: paleoenvironmental analysis despite the perils of preservation: PALAIOS, v. 2, p. 543-559, doi: 10.2307/3514492.

FÜrsich, F.T., AND OschmanN, W., 1993, Shell beds as tools in basin analysis: the Jurassic of Kachchh, western India: Journal of the Geological Society, v. 150, p. 169 185, doi: 10.1144 /gsjgs. 150.1.0169.

González, S., Carranza, A., Scarabino, F., De Mello, C., and Ligrone, A., 2011, Coexistence patterns of benthic gastropods: the genus Buccinanops (Nassariidae) in the inner Uruguayan continental shelf and the Río de la Plata estuary: Pan-American Journal of Aquatic Sciences, v. 6, no. 3, p. 247-259.

Gordillo, S., 2006, The presence of Tawera gayi (Hupé in Gay, 1854) (Veneridae, Bivalvia) in southern South America: Did Tawera achieve a late Cenozoic circumpolar traverse?: Palaeogeography, Palaeoclimatology, Palaeoecology, v. 240, p. 587-601, doi: 10.1016/j.palaeo.2006.03.009.

Gordillo, S., ANd Archuby, F.M., 2012, Predation by drilling gastropods and asteroids upon mussels in rocky shallow shores of southernmost South America: a multi-faceted approach: Acta Palaeontologica Polonica, v. 57, p. 633-646, doi: http://dx.doi.org/10. 4202/app.2010.0116.

Gordillo, S., AND Archuby, F.M., 2014, Live-live and live-dead interactions in marine death assemblages: the case of the Patagonian clam Venus antiqua: Acta Palaeontologica Polonica, v. 59, p. 429-442, doi: http://dx.doi.org/10.4202/app.2011.0176.

GuiŇEZ, R., AND CAstilla, J.C., 1999, A tridimensional self-thinning model for multilayered intertidal mussels: The American Naturalist, v. 154, p. 341-357, doi: 10 . $1086 / 303234$.

Hammer, O., and Harper, D.A.T., 2006, Paleontological Data Analysis: Oxford, UK, Blackwell Publishing, 351 p.

Hammer, O., Harper, D.A.T., And Ryan, P.D., 2001, PAST Paleontological Statistics software package for education a data analysis: Palaeontologia Electronica, v. 4 (1), 178 kb, http://palaeo-electronica.org/2001_1/past/issue1_01.htm. Checked December 2014.

HulberT, S.H., 1971, The nonconcept of species diversity: a critique and alternative parameters: Ecology, v. 52, no. 4, p. 577-586, doi: 10.2307/1934145.

Kidwell, S.M., 1985, Palaeobiological and sedimentological implications of fossil concentrations: Nature, v. 318, p. 457-460, doi: 10.1038/318457a0.

KIDwELl, S.M., 1986, Models for fossil concentrations: paleobiologic implications: Paleobiology, v. 12, p. 6-24.

Kidwell, S.M., 2001, Preservation of species abundance in marine death assemblages: Science, v. 294, p. 1091-1094, 10.1126/science.1064539.

KIDWELL, S.M., 2002, Mesh-size effects on the ecological fidelity of death assemblages: a meta-analysis of molluscan live-dead studies: Geobios Mémoir Spécial, v. 24, p. 107-119.

KIDWELL, S.M., 2007, Discordance between living and death assemblages as evidence for anthropogenic ecological change: Proceedings of the National Academy of Sciences USA, v. 104, p. 17701-17706, doi: 10.1073/pnas.0707194104.

KIDWELL, S.M., 2013, Time-averaging and fidelity of modern death assemblages: building a taphonomic foundation for conservation palaeobiology: Palaeontology, v. 56, p. 487-522, doi: 10.1111/pala.12042.

Kidwell, S.M., And Bosence, D.W.J., 1991, Taphonomy and time-averaging of marine shelly faunas, in Allison, P.A., and Briggs, D.E.G., eds., Taphonomy: Releasing the Data Locked in the Fossil Record: New York, Plenum Press, p. 115-209.

Kidwell, S.M., And Flessa, K.W., 1995, The quality of the fossil record: populations, species and communities: Annual Review of Ecology and Systematics, v. 26, p. 269 299, doi: 10.1146/annurev.es.26.110195.001413.

Kidwell, S.M., AND Tomašových, A., 2013, Implications of time-averaged death assemblages for ecology and conservation: Annual Review of Ecology, Evolution and Systematics, v. 44, p. 539-563, doi: 10.1146/annurev-ecolsys-110512-135838.

Kidwell, S.M., Fürsich, F.T., And Aigner, T., 1986, Conceptual framework for the analysis and classification of fossil concentrations: PALAIOS, v. 1, p. 228-238, doi: $10.2307 / 3514687$.

Kowalewski, M., Carroll, M., Casazza, L., Gupta, N., Hannisdal, B., Hendy, A. Krause, R.A., Jr., LaBarbera, M., Lazo, D.G., Messina, C., Puchalski, S. Rothfus, T.A., Sälgeback, J., Stempien, J., Terry, R.C., And Tomašových, A., 2003, Quantitative fidelity of brachiopod-mollusk assemblages from modern subtidal environments of San Juan Islands, USA: Journal of Taphonomy, v. 1, p. 43-65. 
Liebig, P.M., Taylor, T.S.A., And Flessa, K.W., 2003, Bones on the beach: marine mammal taphonomy of the Colorado Delta, Mexico: PALAIOS, v. 18, p. 168-175, doi: $10.1669 / 0883-1351$.

Lomovasky, B.J., Brey, T., Morriconi, E., and Calvo, J., 2002, Growth and production of the venerid bivalve Eurhomalea exalbida in the Beagle Channel, Tierra del Fuego: Journal of Sea Research, v. 48, p. 209-216, doi: 10.1016/S13851101(02)00133-8.

Lomovasky, B.J., Brey, T., And Morricone, E., 2005, Population dynamics of the venerid bivalve Tawera gayi (Hupé, 1854) in the Ushuaia Bay, Beagle Channel: Journal of Applied Ichthyology, v. 21, p. 64-69, doi: 10.1111/j.1439-0426.2004.00599.x.

LóPEZ GAPPA, J.J., TABLADO, A., AND MAGALDI, N.H., 1990, Influence of sewage pollution on a rocky intertidal community dominated by the mytilid Brachidontes rodriguezi: Marine Ecology Progress Series, v. 63, p. 163-175, doi: 0171-8630/90/0063/0163.

López, R.A., Penchaszadeh, P.E., and Marcomini, S.C., 2008, Storm-related strandings of mollusks on the Northeast Coast of Buenos Aires, Argentina: Journal of Coastal Research, v. 24, p. 925-935, doi: 10.2112/05-0621.1.

Márquez, F., and Van Der Molen, S., 2011, Intraspecific shell-shape variation in the razor Ensis macha along the patagonian coast: Journal of Molluscan Studies, v. 77 no. 2, p. 123-128, doi:10.1093/mollus/eyq044.

Martinelli, J.C., Gordillo, S., And Archuby, F.M., 2013, Muricid drilling predation at high latitudes: insights from the southernmost Atlantic: PALAIOS, v. 28, p. 33-41, doi: $10.2110 /$ palo. 2012 .

Miller, J.H., 2011, Ghosts of Yellowstone: multi-decadal histories of wildlife populations captured by bones on a modern landscape: PLoS One, v. 6(3), e18057, doi: 10.1371/journal.pone.0018057.

Miller, J.H., 2012, Spatial fidelity of skeletal remains: elk wintering and calving grounds revealed by bones on the Yellowstone landscape: Ecology, v. 93, no. 11, p 2474-2482, doi: 10.1890/12-0272.1.

Miller, J.H., Behrensmayer, A.K., Du, A., Lyons, S.K., Patterson, D, Tóth, A. Villaseñor, A., KANGA. E, AND ReED, D., 2014, Ecological fidelity of functional traits based on species presence-absence in a modern mammalian bone assemblage (Amboseli, Kenya): Paleobiology, v. 40, p. 560-583, doi: 10.1666/13062

Morsan, E.M., 2007, Spatial pattern, harvesting and management of the artisanal fishery for purple clam (Amiantis purpurata) in Patagonia (Argentina): Ocean and Coastal Management, v. 50, p. 481-497, doi: 10.1016/j.ocecoaman.2006.10.001.

Olivier, S.R., Escofet, A., Orensanz, J.M., Pezzani, S.E., Turro, A.M., and Turro, M.E., 1966a, Contribución al conocimiento de las comunidades bénticas de Mar de Plata. I. El litoral rocoso entre Playa Grande y Playa Chica: Anales Comisión de Investigaciones Científicas, v. 7, p. 185-206.

Olivier, S.R., De Paternoster, I.K., And Bastida, R., 1966b, Estudios biocenóticos en las costas de Chubut (Argentina) I. Zonación biocenológica de Puerto Pardelas (Golfo Nuevo): Boletín Instituto de Biología Marina, v. 10, p. 5-71.

OlszewsKi, T.D., AND Kidwell, S.M., 2007, The preservational fidelity of evenness in molluscan death assemblages: Paleobiology, v. 33, p. 1-23, doi: 10.1666/05059.1.

Pastorino, G., 1994, Moluscos costeros Recientes de Puerto Pirámide, Chubut: Argentina Academia Nacional de Ciencias, Córdoba Miscelanea, 93, p. 1-30.

Pedoja, K., Regard, V., Husson, L., Martinod, J., Guillaume, B., Fucks, E., Iglesias, M., AND WeIll, P., 2011, Uplift of Quaternary shorelines in eastern Patagonia: Darwin revisited: Geomorphology, v. 127, p. 121-142, doi: 10.1016/j.geomorph.2010. 08.003.

Penchaszadeh, P.E., 1973, Ecología de la comunidad del mejillín (Brachydontes rodriguezii d'Orb.) en el mediolitoral rocoso de Mar del Plata (Argentina): el proceso de recolonización: Physis, v. 32, p. 51-64.

R Core Team, 2014, R: A Language and Environment for Statistical Computing Vienna, Austria, R Foundation for Statistical Computing, http://www.R-project.org. Checked April 2015

Rechimont, M.E., Galván, D.E., Sueiro, M.C., Casas, G., Piriz, M.L., Diez, M.E., Primost, M., Zabala, M.S., Márquez, F., Brogger, M., Alfaya, J.E.F., and BigatTI, G., 2013, Benthic diversity and assemblage structure of a north Patagonian rocky shore: a monitoring legacy of the NaGISA project: Journal of the Marine Biological Association of the United Kingdom, v. 93, p. 2049-2058, doi: 10.1017/ S0025315413001069

Ríos, E.C., 2009, Compendium of Brazilian Sea Shells: Rio Grande, R.S., Brazil, Evangraf, 676 p.

Rosenberg, G., 2009, A Database of Western Atlantic Marine Mollusca: Malacolog 4.1.1, http://www.malacolog.org/. Checked December 2014

Rostami, K., Peltier, W.R., and Mangini, A., 2000, Quaternary marine terraces, sealevel changes and uplift history of Patagonia, Argentina: comparisons with predictions of the ICE-4G (VM2) model of the global process of glacial isostatic adjustment: Quaternary Science Reviews, v. 19, p. 1495-1525, doi: 10.1016/ S0277-3791(00)00075-5.

SÁncheZ, V., AND Zaixso, H.E., 1995, Secuencias de recolonización mesolitoral en una costa rocosa del Golfo San José (Chubut, Argentina): Naturalia Patagónica Serie Ciencias Biológicas, v. 3, p. 57-83.

Scarabino, F., Zaffaroni, J.C., Clavijo, C., Carranza, A., and Nin, M., 2006 Bivalvos marinos y estuarinos de la costa uruguaya: faunística, distribución, taxonomía y conservación, in Menafra, R., Rodríguez-Gallego, L., Scarabino, F. and Conde, D., eds., Bases para la Conservación y el Manejo de la Costa Uruguaya: Montevideo, Vida Silvestre Publicaciones, p. 157-170.
Schellmann, G., and RadtKe, U., 2000, ESR dating of stratigraphically wellconstrained marine terraces along the Patagonian Atlantic coast (Argentina): Quaternary International, v. 68-71, p. 261-273, doi: 10.1016/S1040-6182(00)00049-5. Schellmann, G., and Radtke, U., 2010, Timing and magnitude of Holocene sea-level changes along the middle and south Patagonian Atlantic coast derived from beach ridge systems, littoral terraces and valley-mouth terraces: Earth-Science Reviews, v. 103, p. 1-30, doi: 10.1016/j.earscirev.2010.06.003.

Servicio de Hidrografía Naval, 2012, Tablas de marea, http://www.hidro.gob.ar/ Oceanografia/Tmareas/Form_Tmareas.asp. Checked September 2013.

Signorelli, J.H., And Pastorino, G., 2011, Revision of the Magellanic Mactridae Lamarck, 1809 (Bivalvia: Heterodonta): Zootaxa, v. 2757, p. 47-67.

Signorelli, J.H., Marouez, F., and Pastorino, G., 2013, Phenotypic variation of south-western Atlantic clam Mactra isabelleana (Bivalvia: Mactridae): Journal of the Marine Biological Association of the United Kingdom, v. 93, p. 511-517, doi:10. 1017/S0025315412000410.

Silliman, B.R., Bertness, M.D., Altieri, A.H., Griffin, J.N., Bazterrica, M.C Hidalgo, F.J., Crain, C.M., and Reyna, M.V., 2011, Whole-community facilitation regulates biodiversity on Patagonian rocky shores: PLoS ONE, v. 6(10), e24502, doi: 10.1371/journal.pone.0024502.

Terry, R.C., 2010, The dead do not lie: using skeletal remains for rapid assessment of historical small-mammal community baselines: Royal Society Proceedings, B, v. 277, p. 1193-1201, doi: 10.1098/rspb. 2009.

Teso, V., Signorelli, J.H., And Pastorino, G., 2011, Shell phenotypic variation in the southwestern Atlantic gastropod Olivancillaria carcellesi (Mollusca: Olividae): Journal of the Marine Biological Association of the United Kingdom, v. 91, p. 1089-1094, doi: $10.1017 /$ S0025315410001475.

Tietze, E., And De Francesco, C.G., 2012, Compositional fidelity of subfossil mollusk assemblages in streams and lakes of the southeastern Pampas, Argentina: PALAIOS, v. 27, p. 401-413, doi: 10.2110/palo.2011.p11-124r.

TomašovÝch, A., 2004, Postmortem durability and population dynamics affecting the fidelity of Brachiopod size-frequency distributions: PALAIOS, v. 19, p. 477-496, doi: 10.1669/0883-1351.

Tomašových, A., AND Kidwell, S.M., 2009, Fidelity of variation in species composition and diversity partitioning by death assemblages: time-averaging transfers diversity from beta to alpha levels: Paleobiology, v. 35, p. 94-118, doi: 10.1666/08024.1.

Tomašových, A., AND Kidwell, S.M., 2010, Predicting the effects of increasing temporal scale on species composition, diversity and rank-abundance distributions: Paleobiology, v. 36, p. 672-695, doi: 10.1666/08092.1.

Tomašovích, A., AND Kidwell, S.M., 2011, Accounting for the effects of biological variability and temporal autocorrelation in assessing the preservation of species abundance: Paleobiology, v. 37, p. 332-354, doi: 10.1666/09506.1.

Tomašovích, A., Fürsich, F.T., AND Olszewski, T.D., 2006, Modelling shelliness and alteration in shell beds: variation in hard part input and burial rates leads to opposing predictions: Paleobiology, v. 32, p. 278-298, doi: 0094-8373/06/3202-0008.

Trovant, B., Ruzzante, D.E., Basso, N.G., and Orensanz, J.M., 2013, Distinctness, phylogenetic relations and biogeography of intertidal mussels (Brachidontes, Mytilidae) from the South-Western Atlantic: Journal of the Marine Biological Association of the United Kingdom, v. 93, p. 1843-1855, doi: 10.1017/ S0025315413000477.

Trovant, B., Orensanz, J.M., Ruzzante, D.E., Stotz, W., and Basso, N.G., 2015, Scorched mussels (Bivalvia: Mytilidae: Brachidontinae) from the temperate coasts of South America: phylogenetic relationships, trans-Pacific connections and the footprints of Quaternary glaciations: Molecular Phylogenetics and Evolution, v. 82, p. 60-74, doi: 10.1016/j.ympev.2014.10.002.

Tsuchiya, M., 1983, Mass mortality in a population of the mussel Mytilus edulis L. caused by high temperature on rocky shores: Journal of Experimental Marine Biology and Ecology, v. 66, p. 101-111, doi: 10.1016/0022-0981(83)90032-1.

Valentine, J.W., Jablonski, D., Kidwell, S., and Kaustuv, R., 2006, Assessing the fidelity of the fossil record by using marine bivalves: Proceedings of the National Academy of Sciences USA, v. 103, p. 6599-6604, doi: 10.1073/pnas.06012 64103.

Warwick, R.M., AND Light, J., 2002, Death assemblages of molluscs on St. Martin's Flats, Isles of Scilly: a surrogate for regional biodiversity?: Biodiversity and Conservation, v. 11, p. 99-112, doi: 10.1023/A:1014094829984.

Wieters, E.A., McQuaid, C., Palomo, G., Pappalardo, P., and Navarrete, S.A., 2012, Biogeographical boundaries, functional group structure and diversity of rocky shore communities along the Argentinean coast: PLoS ONE, v. 7(11), e49725, doi: 10.1371/ journal.pone.0049725.

YANES, Y., 2011, Anthropogenic effect recorded in live-dead compositional fidelity of land snail assemblages from San Salvador Island, Bahamas: Biodiversity and Conservation: v. 21, p. 3445-3466, doi: 10.1007/s10531-012-0373-4.

Yanes, Y., Tomasovych, A., Kowalewski, M., Castillo, C., Aguirre, J., Alonso, M.R., AND IBÁÑEZ, M., 2008, Taphonomy and compositional fidelity of Quaternary fossil assemblages of terrestrial gastropods from carbonate-rich environments of the Canary Islands: Lethaia, v. 41, p. 235-256, doi: 10.1111/j.1502-3931.2007. 00047.x.

ZaIXso, H.E., And PAstor, C.T., 1977, Observaciones sobre la ecología de los mitílidos de la ría Deseado: Ecosur, v. 4, p. 1-46. 
Zuschin, M., And Oliver, P.G., 2003, Fidelity of molluscan life and death assemblages on sublittoral hard substrata around granitic islands of the Seychelles: Lethaia, v. 36, p. 133-150, doi: 10.1080/00241160310001650.

Zuschin, M., AND STACHowitsch, M., 2007, The distribution of molluscan assemblages and their postmortem fate on coral reefs in the Gulf of Aqaba (northern Red Sea): Marine Biology, v. 151, p. 2217-2230, doi: 10.1007/s00227-007-0656-6.
Zuschin, M., Hohenegger, J., and Steininger, F.F., 2000, A comparison of living and dead molluscs on coral reef associated hard substrata in the northern Red Sea: implications for the fossil record: Palaeogeography, Palaeoclimatology and Palaeoecology, v. 159, p. 167-190, doi: 10.1016/S0031-0182(00)00045-6.

Received 29 June 2014; accepted 26 April 2015. 